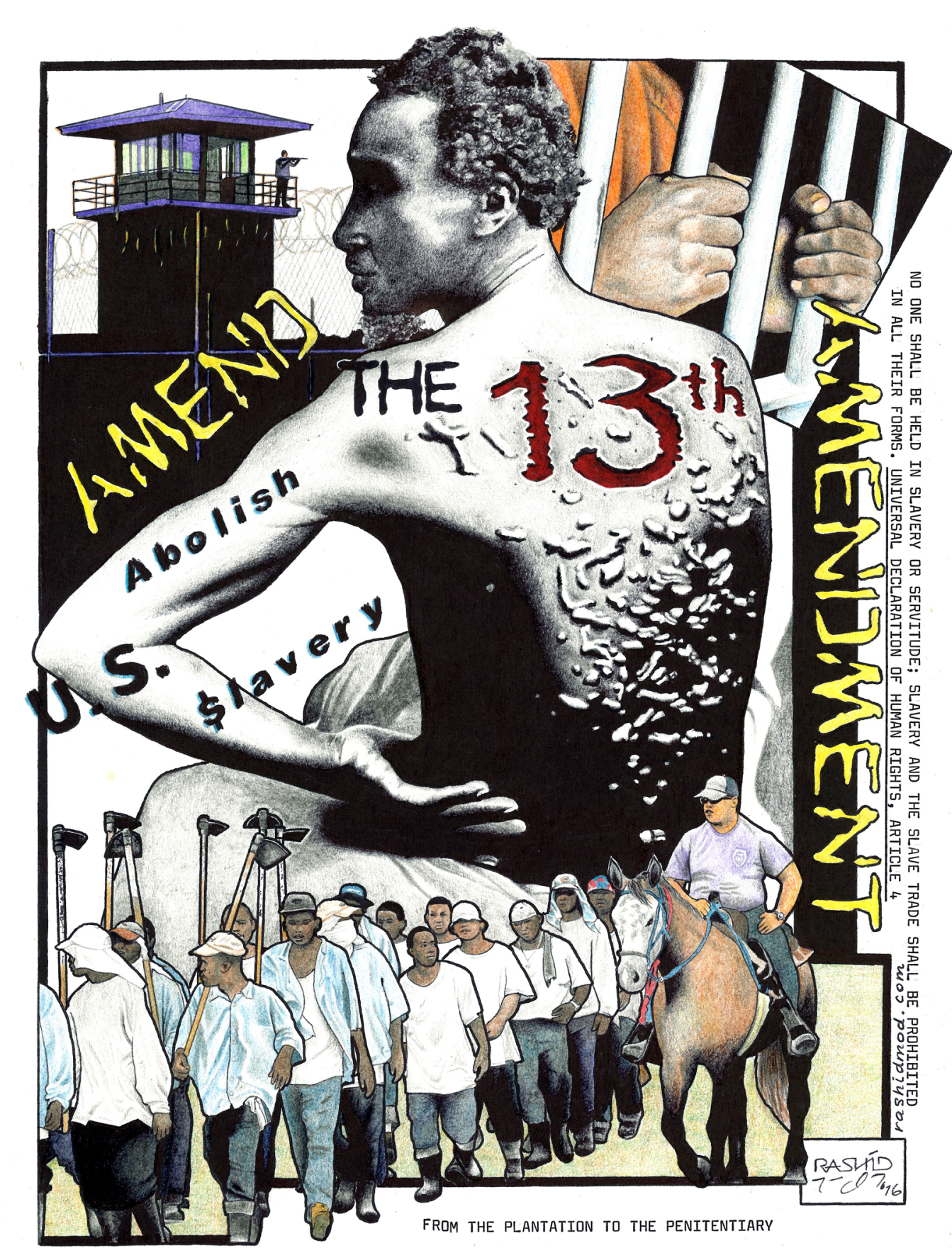

\title{
mind THE FIRE INSIDE
}

fireinside.noblogs.org 


\section{IMAGES}

pp 1. Texas work march

pp 10 prisonstrike.org website.

pp 14 Holman Prison, Atmore, AL. Mar 2016

pp 25 Oakland, CA. Sep 2016

pp 35 Korydallos Prison, Greece. Sep 2016

pp 40 from IamWeUbuntu.com

pp 43 Atlanta, GA. Sep 2016

pp 44 Austin, TX. Sep 2016

pp 55 Lansing, MI. May 2017

pp 56 Waupun, WI. Aug 2016

pp 63 Columbus, OH. Aug 2016

pp 64 Kinross CF, MI. Sep 2016

Back cover: art by Kevin 'Rashid' Johnson, Minister of Defense, New African Black Panther Party-Prison Chapter, Rashidmod.com

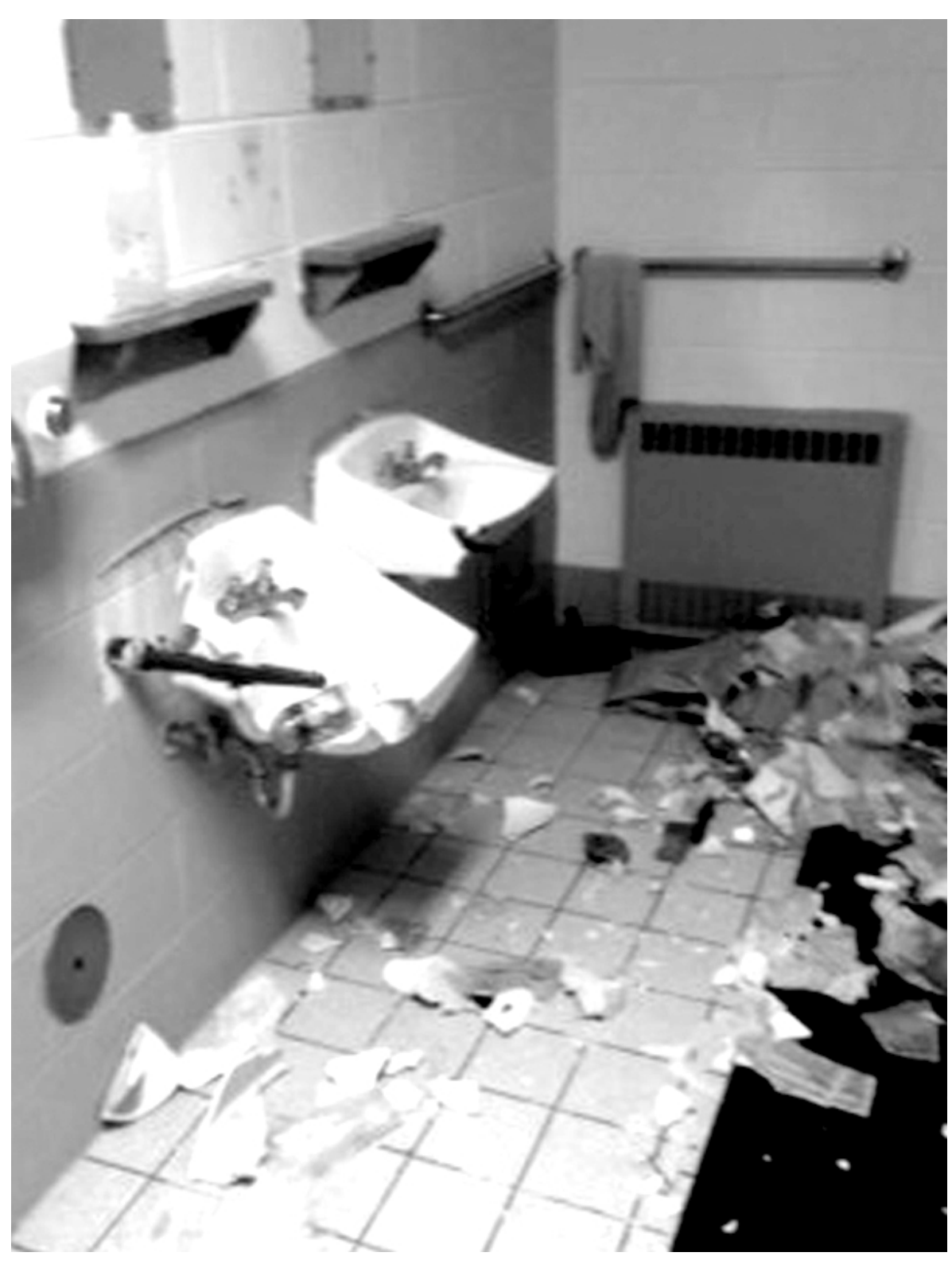


Kite Line Radio -

kitelineradio.noblogs.org PO Box 2422, Bloomington, P.O. Box 411074, San Francisco, CA 94141

Rustbelt Abolition Radio rustbeltradio.org Indiana 47402

Prison Radio - prisonradio.org

The Thread -

defeatmassincarceration.com The Thread/Broken On All Sides 419 Johnson St. Suite 102, Jenkintown, PA 19046

*Project on hold due to lack of funds, may not reply.

Twin Cities IWOC Podcast https://incarceratedworkers.org/ resources/twin-cities-iwocpodcast---storiesinside-"because-they-have-badge

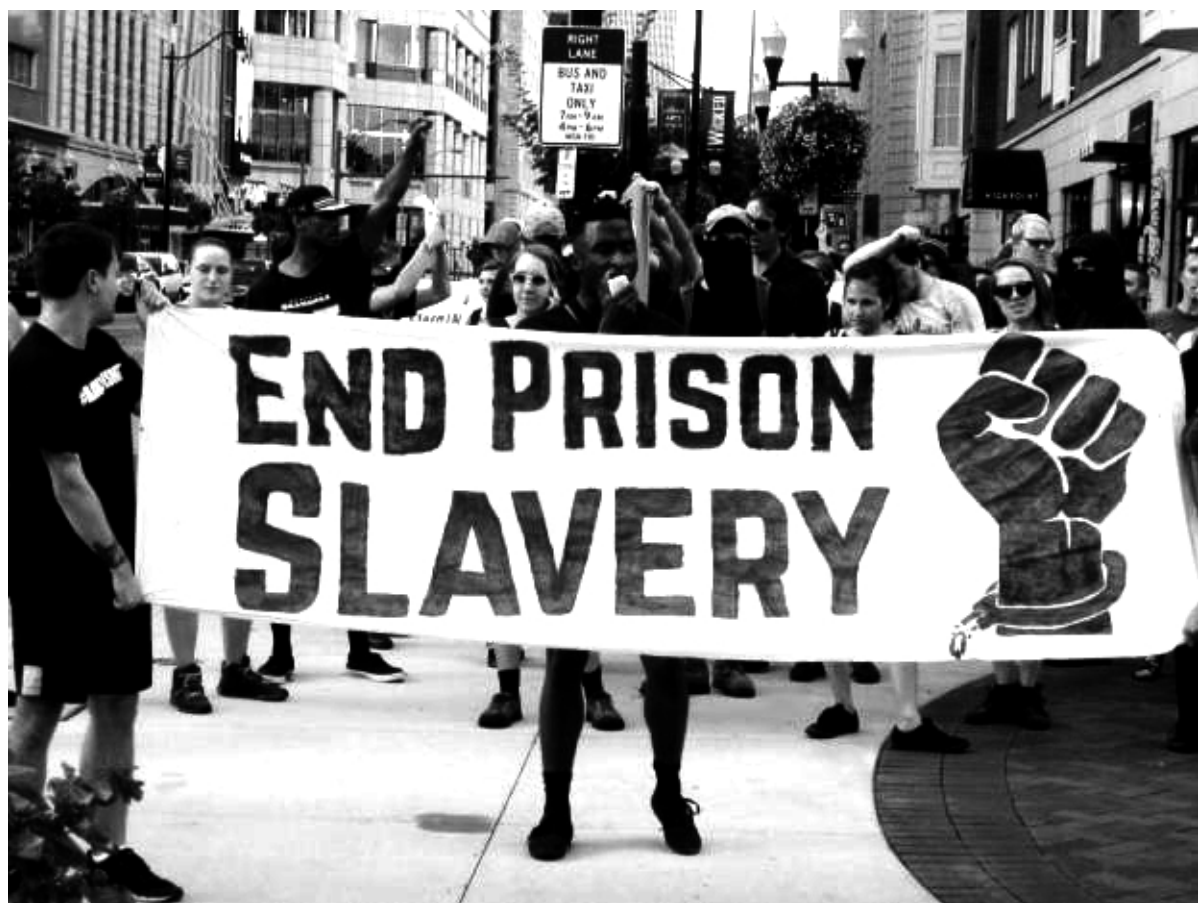

\section{FIRE INSIDE}

\section{TABLE OF CONTENTS}

Introduction pp. 1-3

Reasons for the September 9th Strikes. .pp. $3-10$

Preparations. pp. 10-14

Strategy: Organizing in Prison. pp. 14-21

Strategy: Generalizing Revolts beyond Strikes..... pp. 21-23

Strategy: Interfacing with Prison Hierarchies...... pp. 23-25

Support: What Worked. pp. 25-30

Support: What was Needed pp. 30-33

Support: Prisoner Independence. pp. 33-34

Lessons Learned. pp. 35-39

Moving Forward pp. $40-42$

Outside Solidarity and Contributions. pp. $42-58$

Contributing Authors and Addresses pp. 58-61

List of Resources and Organizations. pp. 61-63 


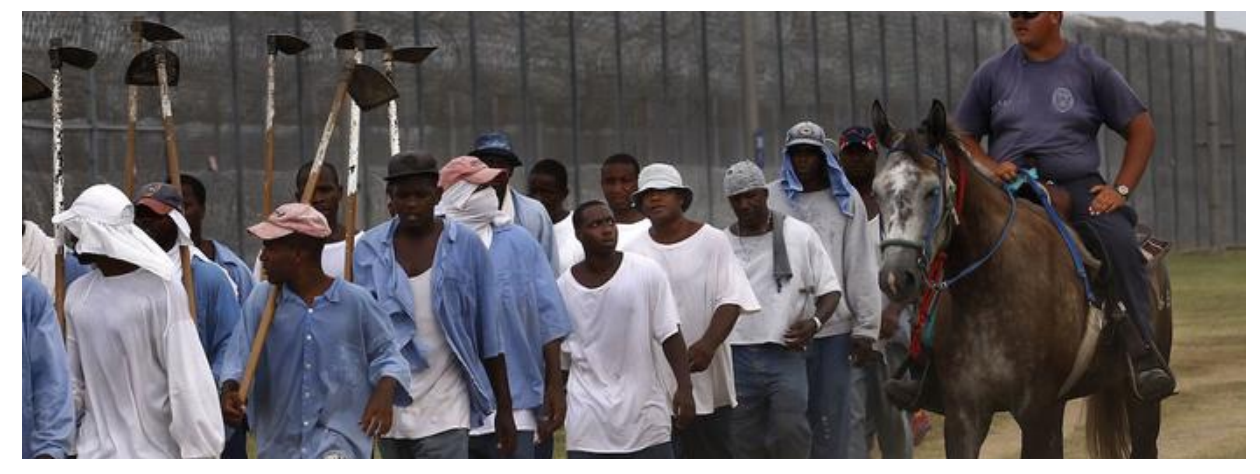

INTRODUCTION

September 9th, 2016 was the first day of the largest prisoner protest in U.S. and possibly in world history. Over 46 facilities experienced work strikes, preemptive shut downs, or some other form of disruption. The Incarcerated Workers Organizing Committee (IWOC) estimates at least 57,000 prisoners participated or were locked down to prevent their participation. The strike was called for by prisoners from across the U.S. and was supported by robust and diverse solidarity actions on the outside. The combined impact of the inside and outside actions was large enough to break through the typical media blockade around prisoner resistance, gaining coverage in mainstream national and local papers, as well as many alternative news sources. In addition to work stoppages and hunger strikes, prisoners in some areas engaged in sabotage and property destruction, tearing down surveillance cameras and smashing whatever they could of the facilities.

These events didn't arise out of nowhere or from nothing; the U.S. has seen expanding prisoner organizing in recent years, and radical communities have been focusing greater attention on prison and related issues. In 2010, prisoners in Georgia staged a state-wide work strike which was the largest in history, until 2016. In 2011 and 2013 California prisoners engaged in massive rolling hunger strikes involving 30,000 participants. These protests inspired lasting prisoner unity in the CA prison system plagued with gang violence and racial divisions. In Alabama, prisoners initiated a steady stream of hunger strikes, work stoppages, and rebellions beginning in 2014 and continuing to the present. They also formed an organization entitled The Free Alabama Movement and outlined a strategy against prison slavery they called "Let the Crops Rot in the Fields" (see resources list). Alabama and Texas

\section{Prisoner Publications}

Black \& Pink - blackandpink.org Black \& Pink National Office, 614 Columbia Road, Dorchester, MA 02125

Maoist Internationalist

Movement -

prisoncensorship.info MIM(Prisons), PO Box 40799, San Francisco, CA 94140

Paw Paw Press: Womxn, Trans, and Queer Prisoners midwestdestructionist.noblogs.or $\mathrm{g}$

$\underline{\text { Revolutionary Abolitionist }}$ Movement (RAM) itsgoingdown.org/author/ra $m$

\section{$\underline{\text { San Francisco BayView }}$}

-sfbayview.com

San Francisco Bay View National Black Newspaper 4917 Third St. San Francisco CA 94124-2309

\section{Podcasts and Radio}

Beyond Prisons shadowproof.com/beyondprisons

Crimethinc's The Exworker Podcast - crimethinc.com
Unstoppable!: Women and Trans Prisoners unstoppable.noblogs.org unstoppable. po box 11032, pueblo, co 81001

Wildfire: Anarchist Prisoner Solidarity - wildfire.noblogs.org on hiatus

Plantation Rising (FL prison strike zine) -

https://fighttoxicprisons.files.wo rdpress.com/2017/06 /17-1212_plantationrisingbooklet1.pdf
The Final Straw -

thefinalstrawradio.noblogs.org

It's Going Down (IGD Podcast) itsgoingdown.org/podcast 
Michael Kimble, Holman prison, Alabama

Write to: Michael Kimble, 138017

3700 Holman Unit

Atmore, AL 36503

Mutope Duguma, Calipatria State

Prison, California

Write to: James D. Crawford,

\#D05996

[In letter, address to chosen name

Mutope Duguma]

CSP Calipatria B2, C-242

PO Box 5005

Calipatria, CA 92233-5005]

\section{LIST OF RESOURCES AND ORGANIZATIONS}

\section{Organizations}

Anarchist Black Cross - search for one - or start one - in your town or city

\section{California Coalition for Women Prisoners -}

http://womenprisoners.org/

\section{Decarcerate LA -}

decarceratelouisiana.com

\section{Fight Toxic Prisons}

-fighttoxicprisons.wordpress.com

Free Alabama Movement http://freealabamamovement.co $\mathrm{m} /$ Solidarity, J22 -

transprisoners.net

Webs of Support -
Siddique Abdullah Hasan, OSP, Ohio

Write to: Carlos A. Sanders, \# R130559

[In letter, address to chosen name Siddique Hasan ]

Ohio State Penitentiary

PO Box 1436

Youngstown, $\mathrm{OH} 44505$ prisoners took intensifying actions leading up to September 9th, including April 4th and May 1st work stoppages, and a steady stream of uprisings and attacks on staff, especially at Holman prison in Atmore, Alabama.

On the outside, The Industrial Workers of the World, numerous ABC chapters, Critical Resistance, The National Lawyer's Guild, and various other groups were involved in support and solidarity. Outside actions around the 9th and days following included marches, blockades, noise demos, general assemblies, letter writing, phone calls to officials, and an attack on a local democratic party office in Bloomington, Indiana. This support was essential to coordinating before the strike as well as slowing repression and gaining mainstream attention during and after. Massive and impactful as these efforts were, prison is still a tragic and terrible part of many of our lives. Sustained strikes, frequent uprisings and continuous protest are needed to render prisons impossible, and so long as they are possible, the ruling class will use prisons to control and maintain this patriarchal, white supremacist and capitalist social order.

Prisoners are going for it. Resistance behind the fences continues. Since Sep. 9th we've seen high profile uprisings and hostage takings at Vaughn Correctional in Delaware on Feb 1 and in Hinton, Oklahoma on July 11. There are also countless daily acts of defiance across the country that largely go unnoticed. Every hour of every day we should expect that somewhere, someone is resisting their confinement. Whether they're flooding cells, and swinging at guards or filing grievances and peacefully defying direct orders, prisoners everywhere are either taking action against the administration, or making plans to. To achieve its full potential, prisoner resistance needs greater coordination, strategic development and outside participation. We need to recognize our achievements and reflect on our shortcomings. We hope this zine is a useful tool to these ends.

thejerichomovement.com

Trans Prisoner Day of Action and

websofsupport.noblogs.org
We've collected reportbacks from both inside and outside organizers, as well as relevant excerpts from other published statements, articles and interviews. We received more response to our queries than we were able to include and had to cut things back. We broke both prisoner letters and outside reports into sections so the different opinions on various topics could be read side-by-side. We included prisoner's names and contact information when they gave us permission, and defaulted to anonymity if consent wasn't given. This zine reflects the varied opinions 
and contradicting thoughts of a resistance movement in development. We believe these points of tension are productive and victory will come from continued experimentation along varied tactical and strategic approaches, so we strive to present them together.

Participants in the Sept 9 actions have called for a March on Washington and solidarity rallies around the country on August 19, 2017. This call emphasizes outside participation, which is too-often lacking.

Demonstrations and marches communicate outside support levels to prisoners, letting them know that they do not struggle alone in obscurity. This helps them plan actions and determine what kind of participation they might rely on from the outside. We encourage people to march, to act in solidarity, and most importantly, to build relationships across the fences. Strong, reliable connections to the outside greatly improve a prison rebel's options and strategic calculations. We also would also like to nurture intentional support networks and in-reach to the prisoners who remain marginal to this movement (and admittedly, this zine): women, trans, queer, indigenous, and undocumented prisoners. There are existing support organizations and/or publications that we've listed in the resources section, and we see efforts to embolden those support crews as ways to help amplify the resistance already occurring among women, trans, queer, indigenous, and undocumented prisoners.

\section{REASON FOR THE SEPTEMBER 9TH STRIKES}

The reasons that prisoners revolt against their conditions are countless. In recent years, the framework that prisons and the carceral state are a continuation of slavery and racialized terror (through the 13th amendment and other legal maneuvers) has entered the public narrative by way of documentaries, best-selling books, fictional media, and public scholarship. Though this understanding is gaining traction, and therefore "credibility," among liberal, non-profit, and other mainstream (read:white heteronormative) circles, the idea that prison is a tool of anti-blackness and social control of the "Other" originates in communities most targeted by policing and prisons. Even before the era of mass incarceration and the so-called war on drugs, Black liberationists, indigenous organizers, trans rebels, anarchists, and other radicals promoted an analysis of the carceral state as one that sought to immobilize effective dissidence within a heteropatriarchal and white supremacist state order. Following the legacy of Leonard
Hakim Akbar-Jones, CSP

Corcoran, California

Write to: Hakim Akbar-Jones, P85158

Corcoran CI

PO BOX 8800

Corcoran, CA 93212

Jason Renard Walker, Clements Unit, Texas

Write to: Jason Renard Walker, 1532092

Clements Unit

9601 Spur 591

Amarillo, TX 79107

Jeremy Valerio, FCI Otisville, New York

Write to: Jeremy Valerio, 40648O50

Federal Correctional Institution PO Box 1000

Otisville, NY 10963

Josh Cartrette (Zero), Snake River correctional Institution, Oregon

Write to: Joshua Cartrette, \#12225965

Snake River Correctional

Institution

777 Stanton Blvd

Ontario, OR 97914

Justin Curtis, Suwannee correctional institution, Florida Write to: Justin M. Curtis, \#K62605

Suwannee Correctional Institution 5964 US Hwy 90

Live Oak, FL 32060
Kat, Franklin correctional institution, Florida

Write to: Steven Thomas \#026260

[In letter, address to chosen name Kat]

RMC West Unit

PO Box 628

Lake Butler, FL 32054

Khalfani Malik Khaldun,

Wabash Valley correctional facility, Indiana

Write to: Leonard McQuay \#874304

[In letter, address to chosen name Bro. Khalfani Malik Khaldun]

PO Box 1111

Carlisle, IN 47838

Kijana Tashiri Askari, CSP SAC, Califormia

Write to: Marcus Harrison \# $\mathrm{H}_{54077}$

[In letter, address to chosen name Kijana Askari]

CSP Sac C5-201

PO Box 290066

Represa, CA 95671

Kinetik Justice, Limestone Correctional Facility, Alabama Write to: Robert Earl Council, 181418

[In letter, address to chosen name Kinetik Justice] Limestone CF D69 28779 Nick Davis Rd Harvest, AL 35749 
Adrien Espinoza, ASPC Kasson, Arizona

Write to: Adrien Espinoza

\#212698

Kasson

PO Box 8200

Florence, AZ 85132

Britney Gulley, Skyview Unit, Texas

Write to: Britney Gulley, 01601283 Skyview Unit

379 FM 2972 West

Rusk, TX 75785

Cesar DeLeon, Dying to Live campaign, Racine correctional facility, Wisconsin

Write to:

Cesar DeLeon, 322800

Racine Correctional Facility

PO Box 909

Sturtevant, WI 53177

Christopher West, Vaughn

Correctional Center, Delaware

Write to: Christopher West

\#415857

JTVCC

1181 Paddock Rd.

Smyrna, DE 19977

Comrade Khaysi, High Security Center, Rhode Island

Write to: Kelvin Canada, 1050088

[In letter, address to chosen name

Comrade Khaysi]

High Security Center
Po Box 8200

Cranston, RI 02920

Derrick Gibson, SCI Forest,

Pennsylvania

Write to: Derrick Gibson JP-2190

SCI Forest

PO Box 945

Marienville, PA 16239

Edgar A Sazo, Gib Lewis Unit, Texas

Write to: Edgar Arturo Sazo,

1671069

Gib Lewis Unit

777 EM 3497

Woodville, TX 75990

El Roderick Mckissick, Hancock

State Prison, Georgia

Write to: El Roderick Mckissick, 792883

PO Box 339

Sparta, GA 31087
Peltier, Assata Shakur, George Jackson, Angela Davis, Oscar López Rivera, Marsha P. Johnson and many others, imprisoned rebels are making the analytic connections between imprisonment and repression of liberatory social movements. In this section, El Roderik, W., Kat, Jason, Hasan, Kinetik, and Michael contextualize prison revolts as a way to negate their enslavement and subhuman treatment. They speak about direct action and work stoppages, rather than making rhetorical appeals to their oppressors, because it is one of the only ways that they can resist a "culture of terror" and a system that profits off of exploitation (labor) and warehousing (incapacitating bodies). An important addition and complement to this conversation is Michael Kimble's piece, entitled The Untold Story, about queer prisoners' involvement in several of the recent Holman rebellions in defiance against a hyperpatriarchal regime and culture. The accounting of recent riots also draws attention to the use of strategic violence in queer history, specifically among incarcerated queers.

\section{El Roderick Mckissick, Hancock SP, Georgia}

Prisons-modernized slavery plantations strategically deprive us of Our Human Rights on all levels but the experience of entering this corrupt system is a educational experience if and when we earnestly apply themselves. I deeply regret that All BLACKS have not realized that slavery never was abolished but strategically and clandestinely implemented under the 13th Amendment of the united snakes constitutions.

Most people have become slaves unto dead slave owners known as dead presidents on the us currency and they ignorantly worship them as idol gods not even consciously realizing that they mendaciously laid the foundation for slavery to still exist in the form of prison. It's a pathetic situation and WE must all do as much as WE can to defeat this diabolical system. -All Power to Us, El Roderick Mckissick

\section{W., anonymous prison, California}

By the way once again thank you for contacting me regarding a lot of prison unrest. I've witnessed it so much as well as having been a direct participant until it really seems as if it is something that's automatic but injustice is more frequent than not, which is why resistance and rebellion become human cries and pleas for relief and human dignity. Most prisons especially here in Calif are without doubt 
some of the most extreme bins and racially divided systems in the united states, so with that said there will always be a need for organized strikes. There never seem to be any need for so call effective communication, since most approaches with the intent to communicate with those in charge of the prison system always fall on deaf ears and no relief is in sight and that is a damn shame. Funny animals of the worst kind are treated more humanely than humans. Sincerely, Love, $W$.

\section{Kat, Franklin correctional institution, Florida}

Hello, I am "Kat" - committed name Steven Thomas - a transwoman currently housed at Franklin Correctional Institution, otherwise known as Facility 113. I am in the process of advocating for the rights of transgender prisoners imprisoned within Florida Department of Corrections - they currently have none, other than to say they are transgender. I hope to change that and get established policy delineating the rights that transgender [prisoners] possess.

On the events of September 9th, you will note most of the disturbances occurred in prisons in North Florida - where the fist of oppression and abuse of prisoners strikes the hardest. A prison system - culture of terror that spreads throughout the prisons because of the hierarchy and promotions in rank that are based on the good ol boy network and rewarded for having the proper attitude towards handling prisoners - through brutality and degradation, humiliation, and dehumanization and not as fellow human beings. - Kat [see Kat's full entry in "Plantation Rising" a zine about the Florida prison strikes, cited in our resources section]

\section{Jason Renard Walker, Clements Unit, Texas}

The New Slave Rebellion

The literal perpetuation of slavery in today's prison system (mainly in Texas) has existed since the 13th Amendment's loophole legally sent slaves from plantation to the penitentiary as commodities of the state. For a very long time the then Texas Department of Corrections was effectively able to hide prison slavery through convict labor/leasing. Even the slaves didn't know they were being used as slaves. It was here in Texas that the racialized southern prison model (that has since drifted across America) morphed out of the slave plantation. The and action in the streets and offices may have gotten more media attention.

If we had known the campaign would go as long as it did (because of force feeding) we could have prepared turn out for the long-haul, had action B planned before action A occurred, so that participants in A could be asked to attend B. We could have put more pressure on public meetings, done the research so we'd know every time and place that DOC officials would be appearing publicly and consistently hound them about the hunger strike and torture. Our outreach to politicians and lawyers would have been more successful if we were getting more media, and we could have got more media with better coordinated, attended and targeted actions.

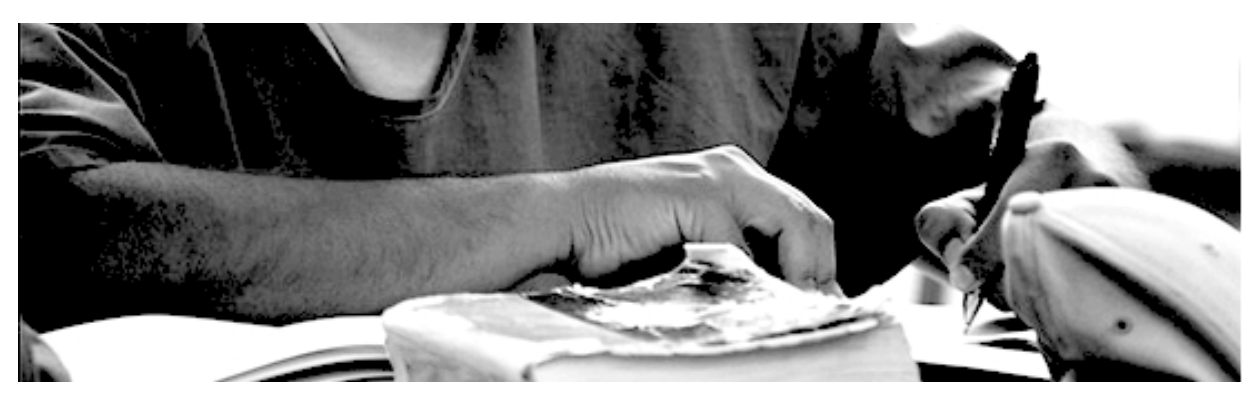

\section{CONTRIBUTING AUTHORS AND ADDRESSES (with consent)}

Some quick tips on writing to prisoners: Prison officials require that legal names be used on the envelope, which often means using slave names or dead names, unfortunately. In the letter, however, you are free to address prisoners by their chosen name. We've marked below where that is applicable. Also, please know that many of those who have written for this zine are targeted and monitored by the prison, including the mailroom pigs. Know that your letters will be closely read and therefore we advise you to either not discuss the strike at all, or to be incredibly careful and indirect. Discussing regular life stuff and politics in general and relaying sentiments of solidarity are definitely advisable and welcomed by folks on the inside. Some concrete tips: write in black or blue ink pen and ask insiders what else might be allowed regarding crayons, colored pens, etc. NYC Anarchist Black Cross has other concrete tips for how to write a letter and also how to keep your correspondences safe: nycabc.wordpress.com/write-a-letter 
escalation when the campaign ended up taking far longer than expected faltered. We hit a breaking point and dropped off support too much too quickly, though we did maintain some different forms of pressure.

The demands were too complex, ambitious and stubbornly held. It would have been better if the initial demand was the single, clearly stated goal that it later became (1 year cap on AC). That demand was too ambitious, it took 30,000 prisoners and multiple lawsuits to put a 10 year cap on solitary in the historic CA hunger strikes. A few dozen prisoners cannot achieve ten times as much as 30K, even if WI DOC wasn't free to force feed. The DOC could not possibly concede this demand. If prisoners had negotiated with the warden and accepted something less which still improved all of their lives and expanded their ability to organize in the future, they would be much better off than the scattered smaller concessions given to the longest individual hold-outs.

These challenges were greatly exacerbated by communication restriction. Censorship in the mailrooms and isolation of the prisoners made it hard to have strategic conversations. Hopefully before the next campaign of this sort, we'd have the capacity to arrange inperson visits. Our lack of resources as far as journalist attention, politicians who will do more than the bare minimum, and legal aid is best solved by shifting the culture in Milwaukee in general to make support for prisoners more of an urgent concern for readers,

constituents, etc, rather than a political liability.

I would have met with the prisoners in person before or immediately after the action started, and discussed timing and demand negotiation strategies with them so that we'd understand expectations better and could share examples of successful step-bystep campaigns for them to consider while negotiating with warden. I would have been more prepared to counter the force feeding narrative, to put polite pressure on the judges (both for the force feeding renewal hearings, and the filing of prisoner lawsuits). We could have filed official looking amicus briefs or open letters, and got well-recognized orgs to sign on, then make every step in the courts something that we hold actions / news conferences, or at least news releases in line with. Our media strategy was haphazard and reactionary, rather than controlling the narrative and setting the agenda. More planning or coordination between action in the courts leasing of convict labor, which has prisoners rented out to the U.S corporations, had these standards set by profiteers in Texas.

So what brought us to this point of national resistance during the post antebellum slave era? Simply speaking, it was consciousness of select prisoners that formed protracted mass movements like the Free Alabama Movement, California's hunger strikes and agreement to end all hostilities, and the End Prison Slavery in Texas campaign. But these movements weren't something that sprouted overnight. After years of prison official's empty promises and our extensive research, we've finally come to realize that the system profits and operates off our exploitation. It's obvious that it has to be shut down at our leisure or they'll keep exploiting us. And the only way this can be done is through collective mass movement - with the effects being a loss of profits for the prison industrial complex and officials having to do the work that we once did. Not to mention an economic ripple effect. ALL POWER TO THE PEOPLE, Jason [see Jason's writings at truthout.org and sfbayview.com]

\section{Siddique Abdullah Hasan, OSP, Ohio}

I do not believe there is a specific or scientific rule on how one should prepare for a "prison strike" or for any other type of strike. However, I do believe that people should be fully committed to their cause and fully conscious of what they're striking for; otherwise, the strike would be headed for failure and possibly disaster. I use the word 'conscious' because I firmly believe that in order for there to be a strike or a revolution (implementation of changes), there must be revolutionary consciousness. That is, people must be fully aware of what they're fighting for and be ready to suffer the possible ramifications of their actions. If they're not fully committed to doing this, then usually they will throw in the towel at the first sign of trouble. There's no room for armchair revolutionaries. Comrade George Jackson said it best when he said: "Revolutionary consciousness is the only real hope of those oppress by the system." The best strategy has been appealing to the consciousness of oppressed peoples, and the least effective has been trying to appeal to the conscience of those in authority. Inasmuch as the latter fully support the super economic exploitation of prisoners and their loved ones, they will never willingly agree to equal pay for equal work when it comes to prisoners. - Hasan [see more at lucasvilleamnesty.org] 


\section{Kinetik Justice, Limestone CF, Alabama}

KINETIK: “...The 13th Amendment was supposedly issued to abolish slavery, however we also have come to understand what it actually did was transform the institution of slavery and codified it so the local, state, and federal government could have a piece of it, rather than just the Southern Agriculture Planter." [The 13th Amendment states, "Neither slavery, nor involuntary servitude shall exist within the United States, or any place subject to their jurisdiction, except as punishment for a crime, whereof the party shall have been duly convicted.] So we wanted to push the envelope, so we got together and we decided to call it May 1st, Mayday, to bring attention back to the state. Don't forget the people who run these prisons have a voice, have a say-so, and we don't agree with building new prisons to deal with the overcrowding, the unsanitary, lack of education. True, a lot of these prisons, need to be torn down and have a new prison built, but that has to be done simultaneously with the process of actually releasing people So, in protest of that, we have engaged in what we call "shut-downs" or a strike where no one in the institution reports to their assigned duties. In these prison institutions all of the labor from the kitchen, to cleaning the floors, cleaning the grounds, landscaping, as well as the industry work, is done by inmate labor, and when there is no inmate labor, the prison doesn't function. When we shut down, just like any business, you're not making a profit on a daily basiswe're losing money on a daily basis. It has worked phenomenally with getting us an audience, and people before the shutdown that no one cared what we had to say and nobody wanted to hear what we had to say. We had no voice, so we cut out the middleman of lobbyists and politicians and we go directly to the legislator, cut out the politicians, and we use our labor as bargaining chips to administer criminal justice reform that is needed in the state of Alabama. Actually we had people locked up in solitary confinement in retaliation, myself, I've been locked in solitary confinement for 28 months from the work strike of 2014. They brought in some new tactics this time. They immediately started by cutting down portions of food on the first day of the strike. We didn't have a balanced meal, and the of ficers kept saying, "If y'all don't like the way the food is, then y'all can go back to work and fix it for yourself." After that didn't work, they went to the work release and I don't know what they promised or what they didn't but they had guys at the work release come to Elmore and Holman in order to perform the jobs of the industry. They weren't

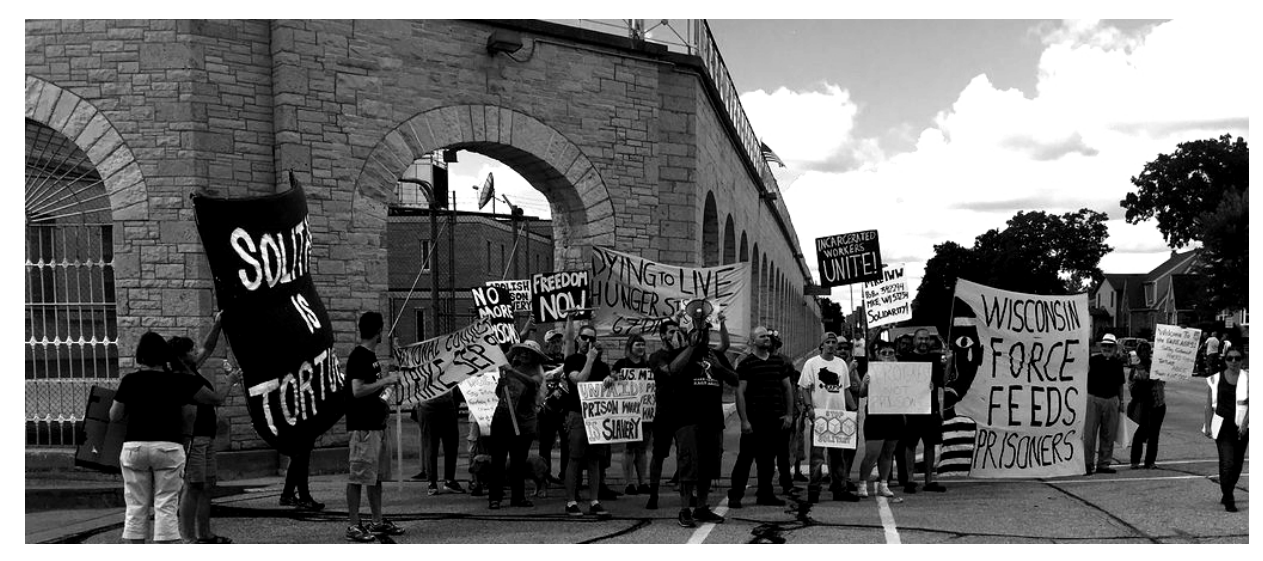

Milwaukee Incarcerated Workers Organizing Committee (IWOC)

Prisoners initiated a hunger strike, called it a food refusal, and demanded limits to the use of administrative confinement. Outside support started with rallies in Milwaukee and Madison, and progressed to marches on the DOC, and a noise demo / march around Waupun Correctional, and flyering around the homes of Secretary Litscher and CO Joseph Beahm's houses. There were also many phone zaps, smaller actions, outreach to politicians, etc.

We mobilized a pretty strong showing of support, in escalating actions up to a point. We got some solid sympathetic media coverage, expanded awareness and troubled the narrative about solitary confinement and prison in WI. In the end the DOC negotiated and conceded improved conditions of confinement for individual prisoners. I understand that this was the largest mass direct action in recent WI DOC history. We forged an effective coalition with FFUP, and a more tense coalition with WISDOM. Relationships with more ambitious or radical members of WISDOM have expanded. Our reach into WI prisons expanded, and our capacity to act spiked, and then fell off, but remains at higher levels than before the strike. There are two prisoner lawsuits that might produce some benefit.

The force feeding was awful (see Dying to Live). For a very long time it felt like the situation was doomed and hopeless because it came into a holding pattern that benefitted the DOC. We were not successful in shaming the DOC about torture and force-feeding. The public conscience and moral compass of the Wisconsin public, representatives, and media is too awry and racist to oppose torture or maintain attention on the force feedings. Our capacity to maintain 
individuals facing mental or physical health crises inside. It's also a challenge to know how to raise our group's public profile in order to reach family members and people inside, while keeping low profiles as individual members, for various reasons related to security. We've dealt with problems of blocked or censored communications and funds. Another challenge is that it's not always clear who the likely political organizers were, who might be newly politicized, and what divisions might exist among groups of people transferred from Kinross. The retaliation was intentionally arbitrary, so that some in segregation were not politically active at all.

We hope that this account will encourage other prisoner solidarity organizing groups to form, with the knowledge that even if you don't know what you're doing at first, there are ways to make it happen. It won't be perfect-we all make mistakes-but it can still be beautiful. It's critical that we share knowledge and experience with each other, because the only thing worse than doing this work poorly is not doing it at all. Whether we're prepared or not, the riots will continue.

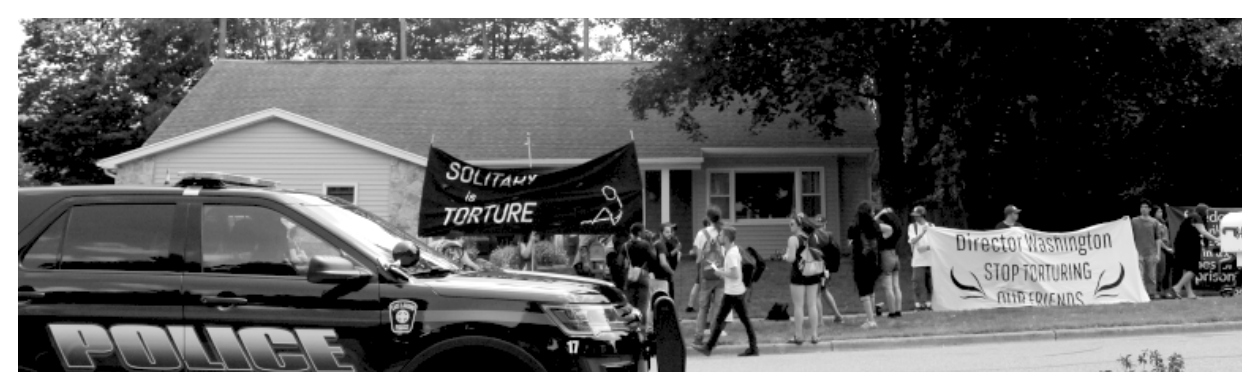

"Addendum: By May 1, over half of those in solitary as a result of Kinross were returned to general population, but around 80 remained. Despite being cleared for release, the warden at the Oaks facility resisted the move. Following a phone blast organized by another local group, on June 11 MAPS organized a "solitary is torture" demo at the home of the director of the MDOC. Family members spoke, recorded interviews with people inside were broadcast, and organizers spoke to neighbors. Contacts at Oaks reported that steps began that same week to move the remaining Kinross group at Oaks out of solitary by July 1." concerned about the rest of the prison running but where they make their money through the industry, because the canning plant is a billion dollar business, and that was what they were more concerned about. Not our humanity, not us eating well, not whether we were facing secure - and they never cleaned the institution. Trash was piled up inside the institution, bacteria, and we argued and complained about the spreading of germs, but what the Department of Corrections was more concerned about was getting workers so they could get paid and that was their first and last agenda.

MATT: So, if I understand you, these were people on work release from another institution that they brought in almost like forced scabs to do the work that would normally be done by you all in the institution?

KINETIK: Yes, correct.

MATT: And, the industry jobs are paid something, right? But are all the jobs paid or are some of them...

KINETIK: No. Actually no jobs are paying jobs in the Alabama prison system except the industry jobs (canning, recycling) and they are paid starting at $\$ 0.15$ an hour and I know a guy who's been working there for 15 years hand he's made $\$ 0.60$ an hour and everything is made out of the institution. There are forced labor jobs where no one is paid but work $8,10,12$ hours a day and receive nothing. However, on the backside of that, we are charged fines and fees yet we work for free. We receive no compensation. Therefore we have established that we are being used to extort money from our family members and loved ones, because when your loved ones send you a few dollars to make sure you have the basic necessities, the DOC freezes the money and takes any money they think they are owed.

Excerpt from an interview on The Thread: A Podcast against Mass Incarceration, episode \#1

[stay updated on Kinetik Justice and the current repression he's experiencing at: freealabamamovement.wordpress.com/tag/kineticjustice-amun/]

\section{Michael Kimble, Holman prison, Alabama}

The web has been abuzz with information about the recent riots here in Alabama at Holman prison - the stabbing of a warden and correctional officer, the fires that were set, the overcrowding, etc. but what has been left out of this narrative is that the catalyst for the riots was a fight between two queer prisoners about queer relations. 
After quelling their beef, a pig and the warden attempted to intervene and was stabbed.

No one wants to mention that out of the six prisoners who were charged with the stabbings of the warden and correctional officer, four are queer. Historically, attempts have been made to write queer resistance out of history. But, despite all the attempts, queer folk have refused to allow these stories to go unknown.

What I think most people refuse to acknowledge is that prisons are extensions of patriarchal control. Male prisons are hyper-macho environments with very hierarchical structures and class divisions. In the prisons, queer prisoners have taken on a submissive and passive persona, because they themselves are not immune to all the psychological bullshit that society teaches about gender, sex, and class, and how that gender should be lived - you know, 'females are weak and only to use, and control.' The queer prisoner is on the bottom of the social ladder, just above snitches. The life of the queer prisoner is one of gross disrespect, violence, and oppression, from prisoners and pigs alike. Most prisoners look at being queer as an abomination, as something nasty and weak.

But on March 11, 2016, that narrative was shattered after queer prisoners went on the offensive against the pigs.

One queer prisoner went from dorm to dorm inviting, exhorting, and encouraging prisoners to come out of their cells and join in tearing the prison down. One dorm refused and placed a lock and chain on their dorm's cell door, successfully locking themselves in and everyone else out. The queer prisoner started calling these guys on this and called them pigs, Uncle Tom, etc. all while brandishing a knife.

And this is not the only instance of queer resistance against the pigs: - In 2012, a stabbing of a guard in the segregation unit at Holman was taking place while showers were being done, and Fredricka, a queer prisoner's, cell door hadn't closed and she ran out the cell, down the stairs and into the control unit. She kicked the pig down who was in the control unit, handcuffed him and opened some of the segregation cell doors, allowing other prisoners to come out their cell and attack the police. be involved in core meetings and decision-making to correspond on our behalf with inside organizers.

When we first formed, we thought that the transfer and dispersal of people from Kinross would be an opportunity to get connected with inside organizers spread throughout the state. We do not know how many people transferred after Kinross were politicized, depoliticized, or intimidated by the events and retaliation, but we suspected that some would continue organizing. However, by December we learned that most of the Kinross people were facing not weeks or months, but one to two years in segregation. Since then, we've channeled most of our energy towards providing those in segregation with much-needed support, solidarity, and voice. They have let us know themselves that we should never underestimate the value of that most basic solidarity. Now that some have been released from segregation, we've begun to reach out to more contacts at other facilities.

Besides media, legal, and correspondence work, our various crews published our first newsletter of prisoner writings for distribution inside and outside, reached out to family members, published a variety of resources on Kinross on the website, and wrote an analysis of the rise of mass incarceration in Michigan, published as a zine. We take seriously the challenge of research, study, and analysis. We understand that we cannot solve the problems we face in our regional geographies and histories (and beyond) without dedicating ourselves to study.

We publicized names of Kinross prisoners looking for public support via IWOC and other outlets, encouraged the formation of multiple letter-writing groups to help us meet that need, and facilitated communication about sending books or funds to those in need. We continue to respond to emergent situations, such as organizing a phone zap for a comrade experiencing intensified retaliation. We work with other groups to share information responsibly and to help get messages out. Some of us are coproducers of the new Rustbelt Abolition Radio, which has featured Kinross voices and analysis in most of its episodes.

Another challenge we've faced is building trust and credibility with those inside, as a new group with a very different politics from the liberal advocacy groups in Michigan with which they're more familiar. We're learning the terrain of other advocacy groups and bodies so that we can refer cases to them when appropriate, such as 
crisis.

IWOC connected us with the nascent National Lawyers Guild legal support team. As we learned names of people inside facing retaliation, we shared them with the legal team and liaised in other ways. The legal collaboration has been time-consuming and sometimes disappointing as the Michigan attorneys tend to think in a legal time frame, not an organizing, political, or media time frame. For example, a FOIA to obtain the names of all those transferred from Kinross got bogged down in delays and miscommunications, and has still not been fulfilled. We may never learn exactly how many and which people were transferred and sentenced to segregation. Prisoners' Legal Advocacy Network (PLAN), a project of NLG-New Jersey/Delaware, has been a great help and collaborator in making this work happen and moving it forward. In future, we would like to cultivate more attorney allies willing to make prison visits.

MAPS grew somewhat and constituted itself as an official group, rather than an ad hoc group, in early November. The work is clearly important, and clearly cannot and should not be sustained by too few people without deeper relationships, infrastructure, and accountability. Before deciding to form a group, we asked ourselves about our organizing priorities, capacity, points of political unity, organizing strategies, and organizational structure and processes. However, due to the urgency of the ongoing work and constantly emergent crises, we haven't had the luxury of answering all these questions in advance; rather, we continue to develop our processes and understanding of ourselves in parallel with diving into the work. For example, we discovered the necessity of having all our decisionmakers on the outside be grounded in, and engaged with, our correspondence with people inside.

Another challenge, as well as strength, is that we're a geographically-dispersed crew of experienced organizers with other ongoing commitments and networks. Our in-person meeting time is limited. We need to grow slowly to maintain good group dynamics and relationships to security culture, but this comes at the expense of overall capacity. We have had to delay or sacrifice some projects we would love to see happen, such as more direct actions, corresponding with more contacts inside, more in-depth writings such as theory pieces and investigative journalism, and further developing our website as an archival resource on Kinross. One strategy we're using to expand capacity is enlisting trusted comrades who don't want to
- Also in 2012 at Holman prison, queer prisoners formed the "Gay Militia" as a prison gang for the protection of themselves against homophobes.

- At Donaldson prison in Alabama, queer prisoners form F.A.G. as a self-defense organization.

- In 2015 at Holman prison, a queer prisoner set fire to a guard in the segregation unit.

The history of queer resistance is long and beautiful. It didn't start with Stonewall. - In Solidarity, Queer Resistance, Michael Kimble [see more of Michael Kimble's writings at anarchylive.noblogs.org]

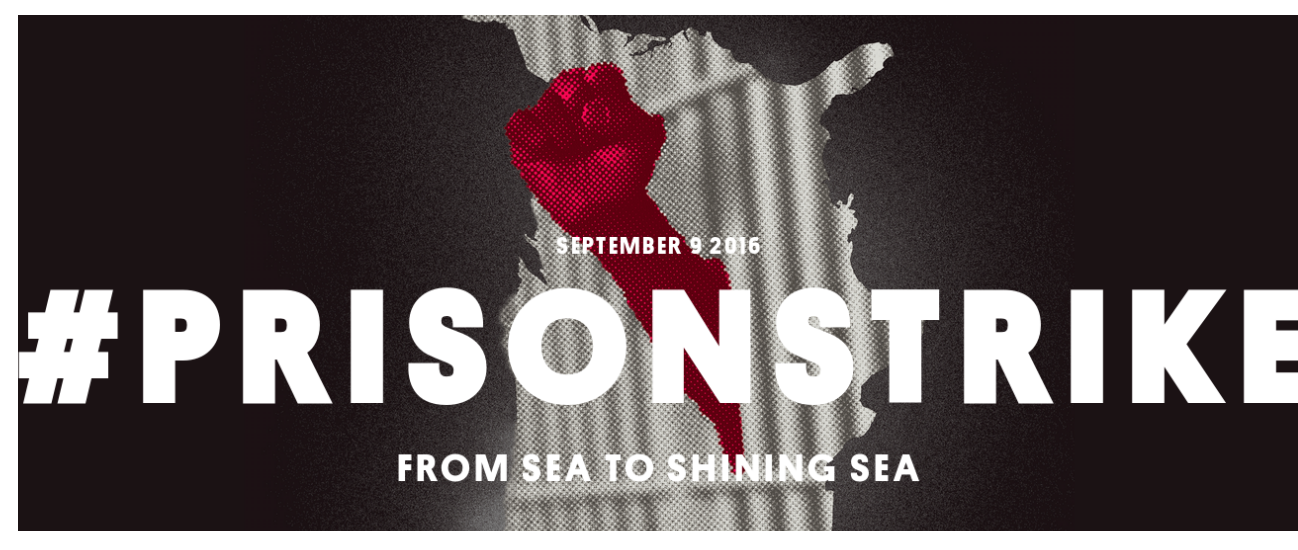

PREPARATIONS

Prison revolts are often spontaneous events, impossible to predict or specifically plan for. Many prisoners approach organizing through a praxis of political education to create a generalized state of readiness should anything pop off. Mutope Duguma speaks to this long-term need for radical education and ways in which to collectivize the struggle in order to transcend the divisions that the prison system perpetuates and exploits. Derrick Gibson gets detailed and practical in his description of lessons learned from repeated hunger strikes. Texas Swamp Monkey describes preparations for the instances when actions can be planned in advance. He contrasts the short term planning for the April 4, 2016 work stoppage that caught Texas officials off guard and the long term build up to Sep. 9, which the correctional officers saw coming for weeks or months. Lockdown bags, secure communication, and preparation for targeted retaliation suggest the 
benefit of some advance planning, though it risks tipping off the authorities.

\section{Mutope Duguma, cofounder of George Jackson University, Calipatria SP, California}

To prepare for a prison strike one has to go through a very grueling educating process as to why the prison strike is absolutely necessary, because prisoners are established inside the prison system on a 'privilege system' where most of them may not even feel oppressed, due to receiving some small tokens... They are divided on a privilege system. So one has to go through a very aggressive education process to get everyone on one accord. Then we begin to prepare by setting in order policies to govern our strike: 1.) Peaceful strike means just that, 2.) No matter what we leave no one behind and our movement is about collective energy moving as one, 3.) It's also important that everyone understand the strategies and tactics that will be employed in the prison strike this way everyone knows exactly what to do or not to do. - All Power to the People, Mutope Duguma, cofounder of George Jackson University [see a collection of Mutope's writings at mutopeduguma.org]

\section{Derrick Gibson, SCI Forest, Pennsylvania}

Preparing for a [hunger] strike and how to organize as an individual you have to formulate a mindset of mind over matter and focus on your objective when participating in a hunger strike. It's usually best for me to consume as much as possible before especially large amounts of meats because they take longer to digest in your body which the first 3 days, about 72 hours, is the hardest and when you'll feel the most hunger pains, they'll lessen or go away after that.

Consume a lot of water, especially when you feel the hunger pains kicking in, it swells your stomach and alleviates them. Conserve your energy by laying down resting, if you're on your feet try to stand in one place instead of continued movement i.e. walking or any exercise because it burns calories and makes you have to defecate. You want to hold your bowel movement as long as possible and only urinate because emptying your fecal matter will bring on or make the hunger pains more intense. Occupy your mind with any and all thoughts except food. a reporter at the Detroit Free Press who is thought to be a leader in prison reporting. However, the resulting article was only slightly critical of MDOC and had a negative slant against our contact and the people at Kinross. Most imprisoned people appreciate this journalist's reporting, but the article felt like a betrayal to the person who took the risk to speak out. We have not communicated with this journalist since, except through press releases. This disappointment highlighted the necessity of developing relationships with more journalists and developing more of our own media.

We shared our Michigan press lists with IWOC and IWOC facilitated sharing our press releases regionally and nationally. Our first press release did not get picked up widely. A few days later we reissued it with an update regarding a man imprisoned at Kinross who had just died due to medical neglect, and we also referenced two other suspicious MDOC deaths in the previous month. Sadly, this was the hook the media wanted, and the news was then picked up by some national outlets. Although people die in prison with terrible frequency, and this is arguably not news, the more sensationalsounding, the more the coverage.

Our primary media strategy has been to amplify imprisoned people's own voices and narratives. We've done this through press releases and interviews, but more so through articles on It's Going Down, the San Francisco Bay View, and our new website, michiganabolition.org. We also collaborated with historian Heather Ann Thompson (Blood in the Water), who was also hearing from family members of people at Kinross, to get words from our contacts into national media. It has been more challenging to get into local/state mainstream media markets than into alternative national and even some mainstream national markets. State media are cautious about angering state agencies, and about angering readers who like to demonize imprisoned people.

We expanded our contact list inside through the help of key comrades in the Midwest who were already in communication with people incarcerated in Michigan prisons, through existing friendships with people inside, and through people inside sharing our contact info with others. We've benefited from advice from formerly incarcerated comrades experienced in inside organizing, from comrades more experienced in outside organizing, and from connection with those who visit people inside and can glean advice in person. All these supports and resources have been invaluable in times of doubt and 
Facility changed all that.

Michigan had two very successful solidarity events on $9 / 9$, one in Lansing and one in Detroit, organized by various emerging groups. There is no IWOC chapter in Michigan and we had not heard of any inside actions planned for 9/9. If IWOC national or other Michiganbased organizers were aware, we were not.

As a result, we first learned of the events at Kinross through mainstream media. We did not begin to learn the reality of what happened until after Kinross came out of lockdown several weeks later. It took months longer to grasp the extent of the retaliationnearly 200 found guilty of incite to riot/strike and sentenced to 1-2 years in segregation. Because of the harsh retaliation and the lack of inside/outside coordination, the demands of protesters at Kinross did not get released to the public until October, and there were other regrettable delays in obtaining names, accounts, and other critical information. We do not think the retaliation will quell the rebellions inside for long. The conditions for those inside have not changedand in many ways have gotten worse-and as such the riots will continue. If nothing else, we hope to be better prepared for the next uprising.

In late September, Ben from IWOC reached out to two of us who had met him at Bend the Bars. He put us in touch with the fiancé of a Kinross prisoner who was not one of those transferred or ticketed, but who bravely wanted to speak out publicly about the abusive retaliation he witnessed. In this period from late-September to lateOctober, a small number of us scrambled to push back against the mainstream media narrative. This narrative sought to alternately minimize the scale of the uprising and demonize those inside for their actions.

First, we initiated a week-long phone zap/call-in campaign to demand an end to the retaliation against folks incarcerated at Kinross. Since we didn't know where those retaliated against had been sent, we included all Michigan prisons with Level IV and higher segregation housing. We also began coordinating letters of support to the handful of people we knew to be targeted for retaliation, but we did not to mention their names in the phone zap because we did not want them to be singled out among the several hundred transferred.

Then, we put out a series of press releases under IWOC's logo and got a little traction in local and regional mainstream media. We coordinated an exclusive interview with our contact inside Kinross for
The less interaction or conversation you have with prison officials or each of your fellow prisoners especially when you are being monitored the better because it shows them that you're serious and may speed up the process of them waiting you out. Refuse to voluntarily give up blood, weight, vital signs etc. Without a court order it definitely speeds up the process because as long as they are charting that they know there's no urgent concern they will definitely play the game and try to wait you out. Do not talk to or air your concerns until you have someone in a higher authority or direct contact with that can address and authorize any solutions to your issues and concerns, they will at first send their pawns to find out what's your issues and concerns then will attempt to figure out a way undermine you or deceive you. In a court of law the prison officials can use persuading and deceive you by lying in order to get you to comply and eat.

If you are recruiting others to participate all of you'll or as many as possible should store away stashes of food for each other especially for the first 3-5 days and if you're consuming food you definitely don't let them take blood, vitals, or weight because they will know it. After your hunger strike is officially recognized by the prison officials and they have moved you to the infirmary or placed you under medical care. They will try to intimidate and frighten with it from the beginning. Fall back let them come to you and don't be eager or keep requesting to speak to them, it shows weakness. - Much love back, Derrick Gibson

\section{The Texas Swamp Monkey, anon prison in Texas}

In 2016 the actions which took place on April 4th caught the oppressors off guard. It was a beautiful thing. The message for the direct action was passed along rather quietly and clandestinely. Surprise is an element hard to acquire in these environments. When the IWOC made the 'Call to Action' available we sat on it for a few months. We saw that the document was prepared well and contained all the info needed in order to educate the prisoners and fellow workers why we were planning the September 9th action and the historical significance of the work strike, so the first thing on the agenda should be educating the masses and raising their awareness that an action is coming. We made 100 copies of IWOC's Call to Action and posted them in every dayroom/TV room on the unit!! So everyone knew including the pigs. 
Because this was bigger than just one unit we made an info pack with flyers in Spanish/English and other items, some specific to the state we were in. For instance, unpaid slave labor is an issue specific to Texas so we highlighted that issue as well as the problem with the good time/work time credits as they relate to parole. Now this was an issue that transcended the barriers of race, religion, and gender!! Every prisoner in Texas knows that the parole system is corrupt, bias, and broken!! Organizing is easier when you have a common cause. It goes without saying one needs free-world logistical help. Copies, mail forwarding, cyber support, and media connects are a must when organizing a national effort. Of course we had and still have a free world comrade who provided incredible support. That comrade became hot as a firecracker and the pigs placed his address on a hot list. So you definitely need multiple reliable contacts. Three per state would be ideal in order to provide adequate support.

It was a mistake to underestimate the treachery of the pigs in the runup to September 9th. Because we were so out in the open with it, the most vocal and active organizers were targeted for retaliation. But the pigs \#1 goal was to neutralize our action. Prisoners in Texas aren't used to these types of actions so it didn't take much to weaken their resolve. Not all prison units are the same. [Some] units are more prone to stand up against oppression. We are still trying to overcome the "Happy Slave" mentality. Many prisoners work with the pigs in order to sabotage our movements. Texas State Prison System (TDCJ) is undergoing a quarter billion dollar budget cut. It won't be hard to capitalize on this. Conditions are getting worse and worse. History has taught us that oppression and repression breed rebellion!!

It is helpful that we start looking at things from a strategic military standpoint because once our action is underway the pigs instantly cut-off all "supply-lines" - food (commissary), phone calls, mail, etc We truly are at a serious disadvantage but there is a solution. We know the pigs are going to lock the unit down once we refuse to work. So weeks in advance we must show some discipline and start assembling lock down bags in multiple locations. These bags containing the basics - lots of soups, beans, and chips. Bottled water may also be advisable depending on your location. But the most important items are stationary! Stamps, paper, envelope, and pens!!
We were only able to have a few educational events in relation to the strike, and this is something we would like to do much more of in the future. Educating those that have not yet been radicalized or introduced to prison strikes and prison abolition is central to building our movement, and this is something $A B C$ needs to improve upon. Having more educational events, as well as having them at a variety of different spaces in town (as opposed to the same bookstore we usually meet at) will make us more accessible.

In a similar vein, we also learned that we need to spend more time involving the immediate community that is not necessarily abolitionist. We want to build stronger relationships with family members of those that have been incarcerated, and we also want to make ourselves more open to the non-radical community. Having more informal discussions, information sessions, and finding ways to promote our message in an accessible way are all things that ABC wants to work on. Although we do not have a clear plan of attack for this, it is something we are prioritizing as a collective.

We also became distinctly aware that we need to be more explicit and transparent about not being able to provide legal support or handle individual cases. Although we can provide assistance with the grievance process by informing folks how it works, we have always maintained that we do not and cannot provide legal support. Despite this, many folks reached out to us for legal support. Being more transparent about the fact that we do not have those abilities will make for more efficient communication.

\section{Michigan Abolition and Prisoner Solidarity (MAPS) michiganabolition.org}

Reflections on Post-9/9 Organizing in Michigan

Michigan Abolition and Prisoner Solidarity (MAPS) formed in the wake of $9 / 9$ events in Michigan. Prior to this, some of us had worked together on LGBTO prisoner solidarity organizing, but none of us had long or deep experience in this realm of organizing. About half of us attended Bend the Bars where we networked with other organizers and absorbed some important basic principles of prisoner solidarity organizing. Independently, several of us had aspirations to do newsletter outreach and to begin what we anticipated would be the slow work of developing relationships with politicized contacts inside. The strike, demonstration, and riot at Kinross Correctional 
updates about the strike and encouraged dialogue between attendees, as well as ideas on how to better support our striking comrades. We were able to cultivate relationships with other activists in town, as well as a few family members of incarcerated people, college students, and sympathetic folks who were curious about what our organization was doing. We encouraged folks to get involved, especially with our call-in campaigns and helping spread the information to our community. Our monthly actions included a noise demo at the Travis County jail, flyering to visiting family members at the Del Valle jail, and two banner drops over high traffic highway bridges.

Media attention and repression slowed down around midOctober. $\mathrm{ABC}$ has maintained relationships with participants and a few family members. Moving forward, we are working to create a newsletter for incarcerated workers in Texas to facilitate communication among prisoners and collective resistance against the prison system. Our first newsletter will be released in July, 2017. We are also working with folks on the inside who will act as a "point person" and collect grievances from their fellow comrades in struggle, so that we can gain a better understanding of what common abuses are happening in each unit, and organize solidarity actions accordingly.

\section{Lessons Learned}

Austin $A B C$ learned a lot of things from this strike. One of the key takeaways was that we should work to build relationships with folks that have potential and desire to strike much earlier. We think we should work to start these communications and relationship-building at least 6 months out. Trust between $A B C$ and striking prisoners is necessary, and we understand the value of building rapport. The longer the relationship and friendship is, the more potential for empowerment and transparent communication, which is central to the facilitating we hope to do around future strikes.

We also learned that it would be best for us to be even more explicit and transparent about our capabilities and capacities as a collective. We are very small in membership and most of us have other work and volunteer obligations, which can cause a delay in communication. Being open about this will allow us to plan better, and will keep everyone involved with us on the same page.
If we can start recruiting lawyers to our movement we will be able to establish secure communications. Cell phones are an extremely valuable resource in this environment. If possible, comrades must secure a device for movement purposes. - END. The Texas Swamp Monkey.

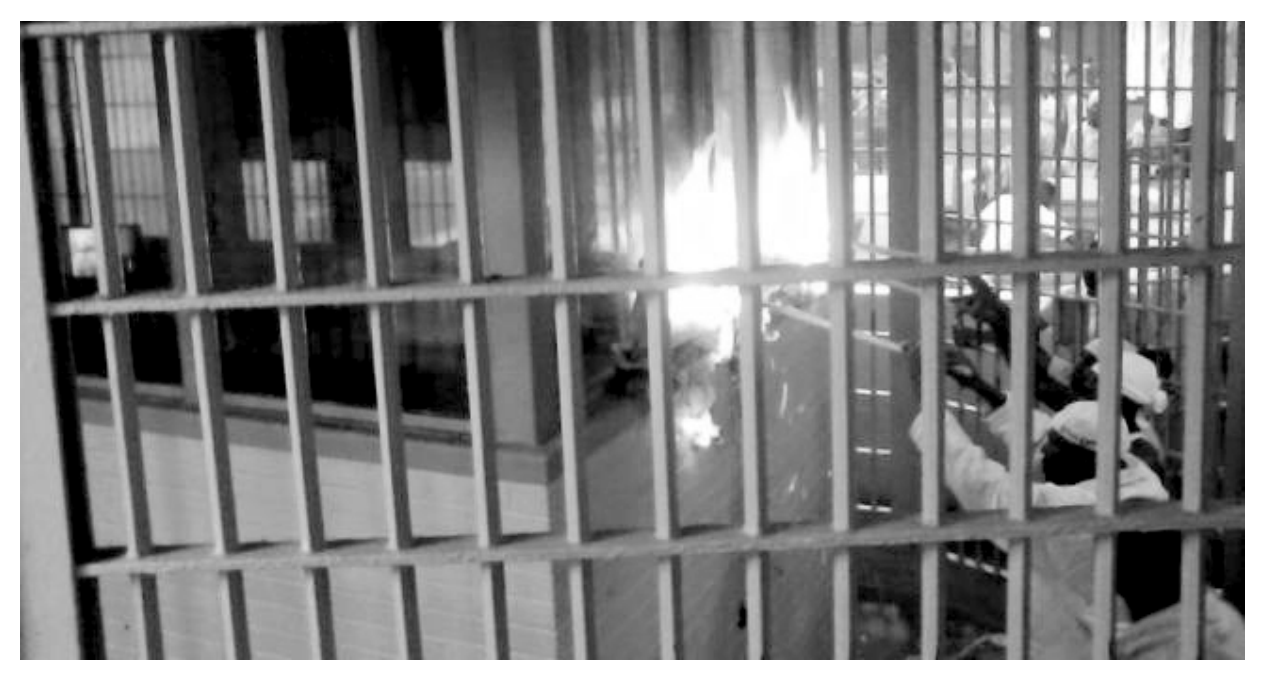

STRATEGY: ORGANIZING IN PRISON

Prisons emerge out of a society based on the social control and suppression of political dissent among groups who have historically been enslaved, disappeared, or caged. Therefore it is predictable that prisons in the U.S. would obstruct political activities among its captives, particularly activities that push for total liberation. By blocking mail and contacts that "pose a security threat," and engaging in preemptive strikes against prisoners who they've identified as leaders or spokespersons prison administrations make organizing exceedingly difficult. These and other methods breed hostile environments that fuel division and conflict among prisoners. In this section, prisoners speak to the need for political autonomy and some of the inventive ways they retain political agency. Mutope speaks against divisions and prisoner hierarchies, and in favor of long term organizing that includes women, trans, queer, disabled, and other "forgotten" prisoners. Chris mirrors these sentiments in building a united front, but also speaks to the kind of revolutionary discipline and personal qualities rebels must have, including getting rid of egotistical 
or selfish motives. R., with Decarcerate Louisiana prioritizes traditional movement building and organizational operations for longterm effectiveness.

In an interesting juxtaposition to these long-game strategies, the latter 3 submissions, anonymous from Florida, anonymous from Michigan, and Justin from Florida, all describe actions that were so spontaneous that they were even unknown to outside supporters until after the fact. The rage described in anonymous from Florida's letter is palpable and has proven riotous. Anonymous in Michigan presents an interesting analysis that "low-security" prisons are actually better to perform collective actions in. Other prisoners often see difficulties mobilizing people in low-security prisons because the stakes are higher (i.e. losing parole or prison incentives), but this account from a Michigan prison where at least 200 protesters took advantage of lower security contexts to pull of a large scale action, tells a different story. Later in this zine, Michigan Abolition and Prisoner Solidarity's (MAPS) statement speaks to how inspiring this action was to their outside organizing. Justin from Florida heard the call to action just one day before participating. He describes the heavy-handed response from the state,which reminds inside prison rebels (and everyone else, really) what kind of monster we're up against. Though Justin is under "closed management status" as a result of his actions, he emphasizes the empowering effects of asserting his political voice. Last, Josh, or "Zero," talks about the need for regional context and specificity to occur when thinking about prison organizing, and also thinking about forming regional networks.

\section{Mutope Duguma, cofounder of George Jackson University, Calipatria SP, California}

We didn't see prisoners as a divided class, but as one class of oppressed people no matter who they were. If they was in prison, they were apart of our system. I hate when activists attempt to classify us by our politics in order to divide us. If women, queers, etc. who are incarcerated are not represented inside the movement, that is $\mathrm{b} / \mathrm{s}$. Because we are fighting for the end of prison oppression and the end to prisons period, where humans are held indefinitely for a profit. So, any achievements affect all prisoners, not just a select few. So, the answer to this question is yes we reached out to every prison state nationwide!!! We did it by educating them to their rights as a human chose to host our demo at the TCI Showroom to prevent them from being able to conduct business on that day. We posted fliers and promoted our event publically, so those that work at TCI were able to find out ahead of time. Since they knew of our event, they had closed off their driveway to send out shipments. Roughly 25 people showed up and made noise for a good portion of the day, and we were successful in halting their business for the entire work day. We had also set a goal of handing the strike demands to those that were employed at the TCI Showroom, and this was also successful. They had security at this event and the security threatened arrests towards those that went to hand over the demands, but no arrests were made.

We did a press release following our noise demo on September 9th. Local media expressed interest in this event, and multiple collective members spoke with media about our activities and the strike. We placed explicit emphasis on the strike being lead by prisoners, as well as sharing the demands made during the strike. Our relation to various trusted leftist reporters remained throughout the duration of the strike, and we prioritized getting media in touch with family members and sharing letters from prisoners who wanted their stories to be made public.

Whenever possible, we make a point to do visitations, and felt that it would be particularly helpful during the time leading up and during the strike. One of our collective members went to visit the Hughes Unit at least once a month. On September 17th during visitation, they got information from three prisoners and one family member that there was repression happening on building 8 of the Hughes Unit. Through their accounts, it was revealed that prisoners overheard on a guard's radio that prisoners in building 8 were striking. They later learned from word of mouth that spread like wildfire that these prisoners had rigged their doors to open at the the same time for the nationwide strike. Guards in riot gear showed up and blasted tear gas and physically restrained and assaulted several prisoners. It was also noted that all prisoners on the unit had received notice that any and all information related to the strike from outside support was forbidden and would be denied. One prisoner said they they overheard on a radio that 13 units were on lockdown.

During the months of August through early October, we committed ourselves to hosting one public meeting and one action or demo per month related to the strike, in addition to our bi-monthly closed collective meetings. During the open meetings, we shared 
able to better target units with a collective idea of what repression folks were facing.

Austin $\mathrm{ABC}$ maintained a working relationship with the New Jersey chapter of the National Lawyers Guild. The NJ NLG offered to file individual "notices of claim" on behalf of each prisoner who faced abusive retaliations. We sent out anti-retaliation letters en masse to the units that were on lockdown or could potentially go on lockdown. These letters contained the information for the NJ NLG, as well as the questions prisoners would need to answer in order for the NLG to file effective claims.

A number of folks that we contacted were interested in receiving our newsletter, as well as being added to our penpal list. We noticed that our mail would often get flagged and blocked, especially on units that were on lockdown. In addition to sending out our own massive mailouts, we also sent out the resource guide and newsletter for a books to prisoners organization. People would also write to us inquiring about how to get involved with IWOC. We made sure to provide these people with IWOC applications and resources, including but not limited to: information for how to receive books, Prison Legal News, and information for Black and Pink.

Individuals from the following units let us know about retaliation, ranging from physical and sexual assault to mishandling of food/food and water restriction/mail blockages: Clements Unit // Stiles Unit // Hughes Unit // Telford Unit // Duncan Unit // Michael Unit // Gib-Lewis Unit

Those incarcerated on the Clements unit spoke of multiple lockdowns, heavy shakedowns, and physical confrontations by correctional officers. The Gib-Lewis Unit faced intense mail blockages, as well as Hughes Unit. We placed special focus on contacting these units at LEAST once day, often times more, asking about lockdowns and the reasons behind it. These units did not provide us with clear or concrete answers - most of our information was from those that were on strike.

Austin $A B C$ had one demo in support of the prisoner strike. Being that Austin is a major metropolitan area, we were not able to get out to an actual prison. We instead hosted our demo at the TCI showroom. Texas Correctional Industries is a corporation that showcases the goods that are made inside of Texas prisons, and sells them to other organizations and companies in Texas. This includes, but is not limited to, colleges, offices, state buildings, et cetera. We being. - All Power to the People, Mutope Duguma, cofounder of George Jackson University

\section{Chris West, Vaughn Correctional Center, Delaware}

The spark fannes [sic] into full revolt. I wish and must draw the distinction between an strike, prison or otherwise, and full scale armed/violent uprising. The two work toward one goal, to lessen or obliterate oppression and exploitation. However, the vast majority of people who are fully committed to revolutionary advancement of human liberty are best suited to work/labor based strikes. Know your strengths, commitments and what you are willing to sacrifice for the cause before ever participating in fighting the tides of fascism, And that gives water a bad connotation! The similarity is only in that, water is difficult to contain, and will take different paths as it advances in ocean waves. So too will those who seek our destruction! We are in a time that we all must realize we are inter-connected and in this existence together, like it or not. The leaders of a strike must possess certain qualities and characteristics. The ability to take criticism from others in regard to personal conduct within the movement is absolutely a foundation for revolutionary leadership. Goals and objectives must be set and adhered to. When reached, pause, reflect, regroup and redirect the mutual energies of the group to the next objective. On occasion, one powerful personality may be best suited to lead for a time, but not to reign omnipotent, thus turning the movement into a personal vehicle for self-advancement, losing sight of the "whole..." p.s. In that spirit, sorry but if you are in any way law enforcement any further inquiry to me or mine is not a good idea for you and yours. Much love! Struggle on! -In Veritas, Chris West

\section{R., incarcerated member of Decarcerate Louisiana at Angola}

No big strikes has [have] ever happened in this prison since the $191 / 2$ years I've been here. They've all been small work or hunger strikes and lasted for no long[er] than a day or a few days and in some cases a few hours. And that's because the upstart strikes have been sudden and merely uprisings, not organizing. Organizing is more informed and strategic and structural - not something you do out of the blue (that's an uprising or buck, to me) because you're so angry or upset about some wrong or injustice. When I think of organizing, I think of an organization - whether it's a non-profit or NGO. Supporters can 
donate money if the organization has a fundraiser. They can pass flyers and brochures out on the outside, or write an article in a newspaper about the issues designed to inform and build awareness. Since appointed or elected public officials claim to be defenders of the city charter, state and federal constitutions and laws, and protectors of basic human rights, you can call them up, point at the problem, and ask for their help. - In Love and Solidarity, $R$ [see more at decarceratelouisiana.com]

\section{Anonymous, prison in Florida}

On Sep 9th at Holmes CI around 9:30 at night a high scale riot took place. Because of the poor food amounts you should consume 2,000 calories a day but we only consume around 1200 to 1500 a day. Plus, the officers were very verbally and physically abusive. And we had enough. On the night of September 9th, A-dorm started first. They blocked the doors and were tearing it apart. Then, B-dorm went the most with more damage than one side. One side of $D$, and one in $\mathrm{E}$ also. In A-dorm they ripped all the cameras down. They tore the ceiling apart, broke all the sinks and toilets and then B-dorm went the hardest. When we went to clean up the dorm, it looked like a hurricane had landed in B-dorm. C-1 was destroyed too. Along with D2, and E1.

After it got so bad the shit eaters came in with full force with shotguns with rubber pellets and tear gas grenades and laid everyone down. Then they were taking one by one zip-tied up to segregative confinement, then threw on the bluebird. These poor men did not even get their property unless it was in their laundry bag packed and ready to go, which no one had time to do. Then, the rest of remaining inmates were left on lockdown for 2 weeks and were unable to leave the dorms. Food was brought to them and no yard exercise or fresh air after that. Things went back to how they were before because they had moved everyone who had been part of it. Roughly 600 people were a part of it in some way.

\section{Anonymous, prison in Michigan}

And the key to the success was to get them all (prisoners) on the same page. What was the foundation to success? The environment. That prison was perfect for what we wanted to do because they could never have locked down. They had men who were willing to stand up participate in the form of a hunger strike; one woman in particular refused food for nearly 2 weeks in order to receive a bra. $A B C$ mobilized a pressure campaign, and did consistent visitations until her demand was met. We feel prisoner lead movements should prioritize the inclusion of queer prisoners, who often face further repression and violence by not only the state, but other prisoners as well.

We were able to foster relationships with four family members of striking prisoners, two wives, one sister, and one mother. We maintained contact with them and received updates from these individuals about their family members, which enabled us to put pressure on the units they are incarcerated at. A few of our collective members met up with these family members, information in regards to any retaliations, as well as provide emotional support. Members of Austin ABC also joined Facebook support groups for family members and loved ones of those incarcerated in Texas. Joining these groups allowed us to gather more information about any repressions or retaliations, as well as allowing us to communicate more openly with family members. We were also able to connect these family members to journalists and media outlets so they could share their stories. We organized a pressure campaign for two prisoners who experienced a significant amount of retaliation for their participation in the strike, including one prisoner who was hit in the knees by the warden and required medical attention. We kept in close contact with their family members, and remained respectful of their wishes on how to handle the pressure campaigns.

We acknowledge the significance of mail, because it alerts prison officials that there is outside support and they are being monitored. We sent supportive postcards to those that went on strike, as well as sent out mass mailouts during the week. These mailouts usually were composed of updates about the strike cleverly masked in other less provocative materials, as well as work that ABC was doing in relation to the strike. We updated folks on things such as: the number of units that were on lockdown that we knew of, the number of striking prisoners that we were aware of, and any communications we had with guards on unit. We also informed striking prisoners about the grievance process should they face retaliation, as well as provided them with other organizations that provide prisoner support. Above all else, we encouraged to folks to keep an open line of communication with us, ensuring that we were 
Upon finding out which units had gone on this pre-emptive lockdown, we sent mail in to ask about retaliation. If folks were retaliated against, we worked towards sending in mail in support of them, as well as calling in to their units to gain updates about their status. One month prior to the strike, $A B C$ also staged a disruption at a Texas Department of Criminal Justice (TDCJ) board meeting. Two individuals made posters, snuck them in, and interrupted the meeting with screams and chants. These individuals were physically and violently removed by the police and were threatened with jail time, but none the less the disruption was successful in stalling TDCJ operations, and showing solidarity with striking prisoners. Houston ABC released a zine called "Incarcerated Workers Take the Lead", which provided a history of prisoner strikes in Texas, and detailed information about the historic significance and upcoming plans for September 9th. Austin ABC mailed these to our contact list (around 200 prisoners), as well as shared them to the general public at MonkeyWrench Books. Once the zines started getting flagged at several units, we collaborated with a local books to prisoners project to release information in their newsletter, which reaches thousands of prisoners per month. To prevent the information from being flagged, we presented it as objectively as possible, with the goal of simply spreading the word. This publication was flagged about 2 weeks into sending it, and we collected denial slips to send to the National Lawyers Guild.

Following the strike, we continued this line of call campaigns and phone zaps. We would call into units daily or every few days and inquire about the lockdown status. We would also inquire about folks that were being retaliated against, putting pressure on the unit to provide us with proper information and stop retaliation. Often times, it was difficult for us to get definitive information out of the units. Units that confirmed they were on lockdown (without answering questions on the lockdowns relationship to the strike) include: Barry Telford, Beto, Connally, Polunsky, Smith, and Torres. As mentioned previously, other units provided us with ambiguous answers about lockdowns. We were not able to get information from any federal units.

It is worth noting that $\mathrm{ABC}$ has always prioritized building friendships and solidarity with trans and gender variant prisoners in Texas, however the overwhelming majority of these prisoners do not work and are placed in a form of solitary confinement called Administrative Segregation. Some of these prisoners chose to in a prison that had no doors, no bars, no rooms. If you want you can go as you please. They (guards) had no way of controlling unless we allowed them to. Which is why so many went with it. Anywhere else and prisoners would not of followed and we would not of been as successful. Even though the higher security is radical and has more risk takers it is not in the best interest for protesting. This is why: there is controlled movement and there is not a time where large amounts of prisoners are out at the same time. They have the manpower to snuff out any fire starters, if you know what I mean. It is not in the best interest to start any protesting in higher levels.

\section{Justin Curtis, Suwannee correctional institution, Florida}

I am 35 years old and have been incarcerated in Florida for almost 14 years straight (minus a brief 2 month taste of freedom in late 2004) and the atmosphere within the FL DOC has been extremely oppressive to say the least. I've talked to other people who have done time in other states and heard of the unity on the part of inmates, but here in Florida that is not the case.

Down here the majority of inmates are out for self, don't care if their fellow inmates have or have not, and the violence, manipulation, and general disregard that occurs from inmate [to] inmate is sad and frustrating. The guards and administration are taught psychological warfare/divide-and-conquer tactics that they implement in plain view for us inmates to see, but due to the majority outlook and selfishness there is never any type of united effort on any front. Several of us talk about standing up, but that's it... until September 9, 2016.

Like I said, the letter detailing the purpose of 9/9/16 came to me on $9 / 8 / 16$. It was forwarded from another institution I had been transferred from. I immediately took action, by passing the letter around, going around and speaking to other inmates who had influence and we agreed that on 9/9/16 we would all participate in a "peaceful sit-down protest." At the time I was assigned to work in food service. I was on the 2 a.m. wake up crew, and we were the ones who would have to start the action. When the COs came to get us up for work (we had already been up all night anxious and excited), we refused to go. The administration was already well aware of what was going to happen and already had plans implemented to bring inmates from the work camp to run the kitchen. So we were placed on 
lockdown status. We watched out of our windows as they called each dorm for chow. Not many people went, except for one dorm where all the inmates went. That is when things got a bit more tense.

As I said, we had no time to plan or prepare, so a lot of people weren't on the same page. Some dudes were arguing "What are we standing up for?" and there were times of tension within our dorm between us. But there was also a sense of unity that I'd never seen. At a certain point to the administration felt it necessary to step down on us. They came in, surrounded the compound with armed police officers, came to our dorm and had us all face down on our bunks, screaming at us through a bullhorn to "Get down!," they had guns over us and totally took the whole thing out of hand. Overreaction puts it very lightly..

After leaving our dorm, the Rapid Response Team (RRT) in full riot gear headed to the two-man-cell dorms, where they rushed in without warning, firing tear gas grenades and rubber bullets at unsuspecting inmates. There were several people punished with bogus Disciplinary Reports (DRs) which all said the same exact thing, and several inmates were transferred to other facilities. I received a DR for "Inciting a Riot" and have been on lockdown since 9/10/16. I am now on Close Management (CM II) status, where I will be on lockdown for at least 7-8 months at Suwannee C.I.

I have no regrets at all besides that there wasn't any time to prepare and have things work out different and perhaps even affect a positive change within this corrupt, oppressive system. But it was a learning experience and I am glad I participated and took action regardless of the consequences... - Justin [see Justin's full entry in "Plantation Rising" a zine about the Florida prison strikes, cited in our resources section]

\section{Josh Cartrette (Zero), Snake River CI, Oregon}

Oregon's and Northwestern general prison industrial complex (PIC) dynamics are vastly different from the greater nationwide PIC. We're about 70\% white and about 99\% dumbfucks who're more geared toward lemmings than human beings. We have a short-sightedness about as far as our own eyelids. Northwestern theory may, however, be applicable to other northern states or midwest or other cracker ass regions. has additional complexity, because some of the hardest fighting people are already serving long sentences and are likely to get charged by internal prison processes, where they are not afforded any real opportunities for legal defense. Also many prison rebels are fighting appeals on cases for which they were originally locked up. Very few lawyers will take on prisoner's cases at all, and they tend to become even more hesitant when someone catches new charges for self defense or resistance activities.

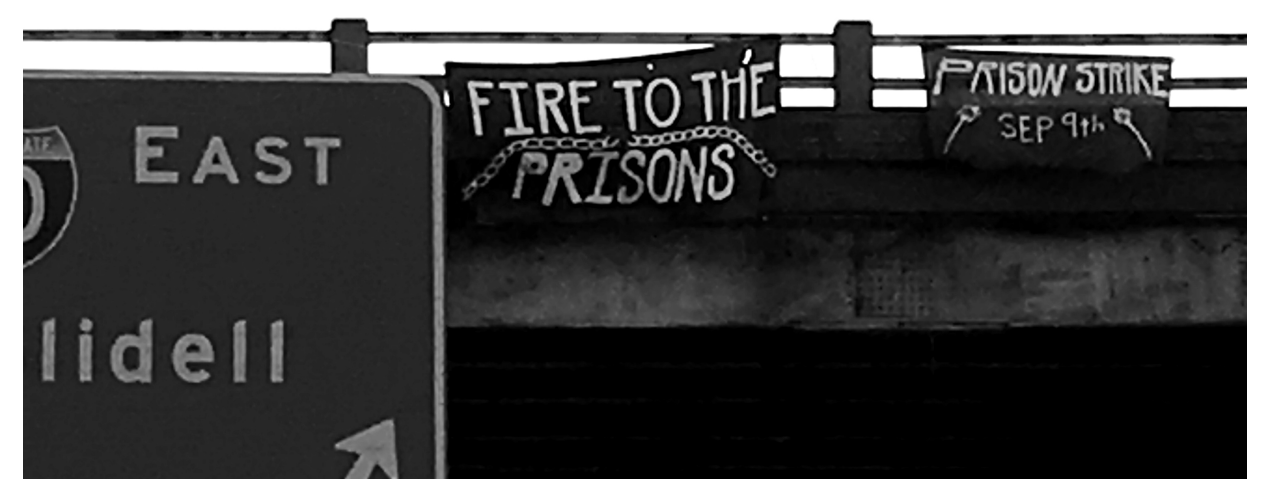

\section{Austin Anarchist Black Cross (Austin ABC)}

How We Participated In the Strike

Austin Anarchist Black Cross (ABC) involved itself with the September 9th Prison Strike in a number of ways. We were able to receive contacts for prisoners in Texas holding an IWW membership through Houston IWOC chapter, whom we shared affinity with and that we have a history of working relationships with. Through our shared contact lists, we were able to write to prisoners about 3 months out from the strike. We were mindful to use an alias, so as not to draw attention to the word "anarchist" in our organization name. We had weekly conference calls with the Houston IWOC to share updates, strategies, and divide the workload.

In preparation for the strike, we organized and participated in call-ins to find out which units went on lockdown. About a dozen units went on a pre-emptive lockdown (we say "about" because a few units would not give an affirmative "yes" but their behavior was highly suspicious and they would not answer the question directly). When asked if these were in relation to work stoppages, the guards on the phone would deny, or outright refuse to answer our questions. 
an earlier timeline and the largest solidarity actions occurred on August 13, when 40 people marched around Waupun Correctional, a prison in the center of a small town with three prisons in it, where nearly every family works as a CO or prison administrator. After the march, some people distributed flyers in the neighborhood of a particularly sadistic guard and the head of the WI DOC. They returned to Milwaukee to support and participate in the spontaneous anti-police riot and uprising in the Sherman Park neighborhood. In Bloomington on the first day of the strike, people attacked a democratic party office, smashing windows, holding up banners and littering the scene with flyers denouncing the Democratic Party's role in expanding mass incarceration and prison society. Some comrades imprisoned outside of the U.S. participated in solidarity actions, most notably anarchist prisoners Luis Fernando Sotelo, Fernando Bárcenas, and Abraham Cortés in Mexico undertook a hunger strike, a courthouse was paintbombed in Bern, Switzerland, prison workers' cars were vandalized in Bristol, U.K, and in Kingston, Ontario, visitors to a prison stopped and handed flyers about the strikes. Banks and corporations using prison labor were also attacked, disrupted or vandalized in Atlanta, Oakland, Barcelona, Portland, and elsewhere.

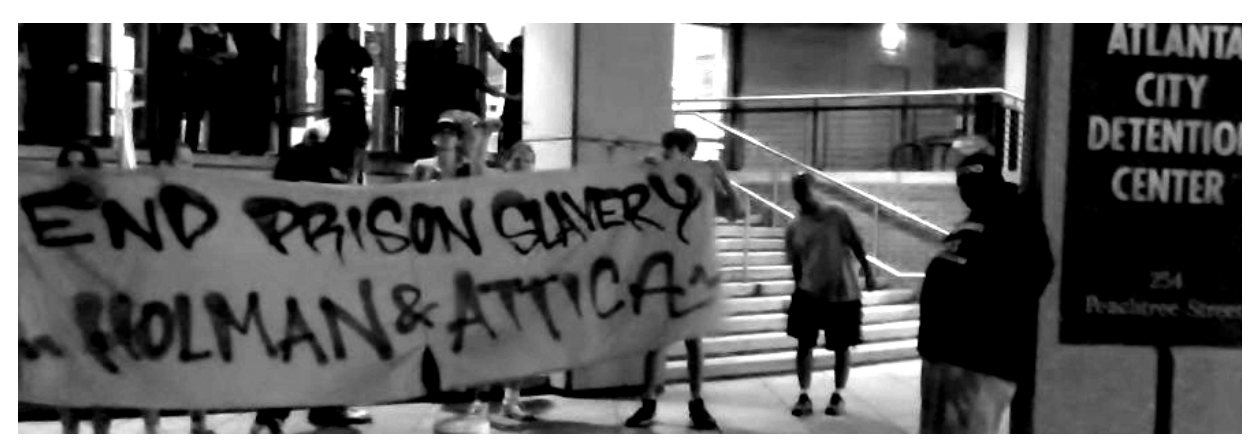

Some outside solidarity actions led to arrests and subsequent legal battles, most notably three comrades charged with heavy felonies in Atlanta for allegedly attacking a Starbucks. As often happens when attacked by the state, the focus of organizing shifted to movement defense and legal support. The prosecution failed to secure convictions thanks to these efforts, but they were successful in draining resources. Whether fighting fascism, imperialism, environmental destruction or prison slavery, we must build movements strong enough to not only win victories on those fronts, but also defend our freedom fighters from the state's response. In the context of prisoner support, this dynamic
Something we're doing in Oregon... it's a good idea to focus on your region/state. What we're doing is running a state PIC-oriented newsletter (The Oregon Prisoner Forum - PortlandPrisonerSupport@riseup.net). Use this to open conversation among your state PIC population to push@narchist ideology and politicize folks inside. This is a slow and lame ass process that's gonna make you wanna drop hand grenades from drones over the fuckin prison yard. But try not to do that as it's bad for public relations.

Unlike "post-slave" states in southern regions, we get payed sustainable wages and shit like hot chocolate with marshmallows on canteen and personal satellite TVs and blah blah, so these fuckin lame dick punk mothafuckers are hard-pressed to buck and get themselves thrown in the box for any length of time and lose they marshmallows. Southern states are slave-oriented due to the historical cultural and economic dependency/conditioning/etc. Cracker states are mostly merely control-based apparatuses. The corporate profiteering shit is minimal and there's way more inmates than jobs - these jobs pay, so mafuckers wnat these jobs. Any workdemo is pointless as all you'll get is an over-abundance of scab punks clamoring. Ain't nobody gonna give up those coveted jobs.

So greater PIC accepted theory/analysis largely doesn't apply. However, the objective is mostly in line. Hit the PIC in the money so you're gonna wanna take a more targeted analysis of your own region/state and build theory accordingly. Use newsletter shit to sorta "fishnet" the greater body; build interpersonal relationships with smarty pants and influential cats.

Back to the money! My personal suggestion is to prioritize, not a labor demo, but a boycott - commissary, phones, any other moneysucking shit these shitbags seduce us with. Aim for a two-month boycott for certain tactical details I'll spare you with. But take whatever you can get - if anything. Ideally, such boycotts can work in conjunction with labor demos, so I'd say this tactic would also be applicable to basically all PICs.

Perhaps, depending on how tight the mail-snipes are around your area, you could try and flood these shit-holes with flyers outlining a brief explanation of WTF you tryin to crack off and the dates between 
which you tryna do it. That'd be Sept 9th till infinity. Or Nov 9th would be nice. Try and make a point for mafukas to not stock up on they marshmallows before hand, etc. For obvious fucking reasons. If you can get even a notable fraction of these dickweeds on board call it a success. Wash, rinse, repeat in 2018. - Forward Hooo! Zero the Bully Slayer, Josh Cartrette [for a link to Josh's fundraiser and more info on his transition home, see itsgoingdown.org/

help-prison-rebel-joshua-cartrettes-transition-home/]

\section{STRATEGY: GENERALIZING REVOLTS BEYOND STRIKES}

The call out for September 9th focused on the tactic of work stoppages as one of the more effective ways to impact prison operations and prison profiteers by withholding slave labor. Once this call was in public circulation, we heard critiques of this focus. Though prisons do exploit prisoners' labor for minimal pay (or in some states, no pay at all), there are estimates that just 90o,ooo of the 2.3 million incarcerated population works. That leaves more than half of those who are incarcerated who do not work at all and are warehoused. Work stoppages certainly do have an impact, and often economic hits gain the most attention, but this particular method did not resonant with all prisoners. Extending Zero's commentary on how work stoppages are not effective at his facility, Adrien offers insight on the fact that jobs are scarce at his prison and asks organizers to reimagine actions in ways that are more relevant for prisoners like him. Kijana, who was recently released from solitary confinement in a california prison as a result of the historic 2013 hunger strikes offers alternative actions, in light of Adrien's critiques, including fasting, political education work, and producing prisoner-centered knowledges. Last, Jeremy discusses the induced isolation and alienation that comes from SHU/SMUs (special housing or management units) and/or federal penitentiaries.

\section{Adrien Espinoza, ASPC Kasson, Arizona}

I would participate but I can't. Inmates here have to kiss ass for up to a year to get a job. If I did participate what am I supposed to do then? Get a job just to strike/quit? They'll hire someone else within 24 hours, some sellout punk. But that's Kasson... That does not mean I wouldn't love nothing more than to shut Kasson down with a strike - I just don't believe it's possible at this unit. Now, if you had someone to going anywhere until we have achieved some meaningful revolutionary changes. (Seeing that prison directors and/or commissioners are appointed by the governor in each respective state, and governors are elected by the people, people have to start turning their undivided attention to governors. Demands and meetings should be made with governors, not with directors and commissioners.) Equally important, everyone must understand that Rome was not built in one day, so we have to stay the course until we achieve our creative goals. - Hasan [see more at lucasvilleamnesty.org]

\section{Jason Renard Walker, Clements Unit, Texas}

Organizing against the establishment, whether it's government officials or prison officials, isn't easy. They hold a certain level of prestigious power which ultimately give them the ability to create rules and policies that keep us at a disadvantage. The minute we figure out a legal way to organize around their polarization, they break their own rules to keep us contained.

This is the motivation and driving force to our resistance: knowing that the politics of polarization and containment in America is racialization and incarceration. It keeps us divided at odds with each other and exploited and repressed by the penal system at the same time.

This reality is how we got to the conclusion that if we don't come together and let the crops rot in the fields, we'll continue to be exploited, divided and promoted to be the musters of our own slavery and eventually the masters of our own destruction. Dare to struggle dare to win! - ALL POWER TO THE PEOPLE! Jason

\section{OUTSIDE SOLIDARITY AND CONTRIBUTIONS}

Outside support for the strike included hundreds of actions across the US and abroad. There were rallies and banner drops, noise demos and rowdy marches. We'd like to highlight a few of the more creative and confrontational acts of solidarity. Outside Tucson $A Z$ radicals built a highway blockade that prevented people from reaching a correctional officer's conference. In Wisconsin, the Dying to Live hunger strike set 
called for on Aug 19 are opportunities to show prisoners that they do not act alone. The contributions in this section recognize the potential of August 19, but underline that there is no replacement for long-term commitments and relationship building to relay information and coordinate strategy and expectations across the walls and beyond them.

\section{El Roderick Mckissick, Hancock SP, Georgia}

When Afrikans/Blacks have unequivocally Built a Invincible Unity Amongst Their Own then and only then can they fully unify with others because if they do not have indestructible unity amongst theirselves then they can be exposed to divide and conquer tactics and mendacious strategies of infiltration by unconsciously embracing the disguised enemies/pigs within it's fold. My Loyal comrades have positions of authority and will continue to move forward in Our Mission but WE will need more support in this state even if we have to connect with outside supporters from other states. - All Power to Us, El Roderick Mckissick

\section{Mutope Duguma, cofounder of George Jackson University, Calipatria SP, California}

My vision for the 'action' [on August 19th] is for it to be made known to the world that Amerika incarcerates $90 \%$ of its poor people, and that the judicial system is complicit in the conspiracy to exploit the [working] class. Poor [residents] of this nation are modern day slaves. End the 13th amendment of the US Constitution that legally sanctions slavery in this country... Prisons destroy families. - All Power to the People, Mutope Duguma, cofounder of George Jackson University

\section{Anonymous, prison in Michigan}

Even though we all got caught up, the system had to change a lot because of us. Although for some it was difficult to accept and even regretted it, it was a worthy sacrifice for the masses. Yes, we are facing retaliation, but we are still the topic of conversation as far as change is concerned.

\section{Siddique Abdullah Hasan, OSP, Ohio}

A call has been made for there to be a rally and protest in Columbus, Ohio, on said date. I fully endorse that call. My vision is to make our presence known and respected. We are here to stay and we're not pay each worker to quit his job that'd be another story. So, do you know any rich people who are anti-prison? Tell each inmate "quit your job and I'll pay you what you would've made in 6,8,12 months." Which isn't much, considering they make between 10 cents and 25 cents per hour and can get a max of 80 hours every two weeks - most don't get that much. - Sincerely, Adrien Espinoza

\section{Kijana Tashiri Askari, CSP SAC, California}

Now to the issue of the prison strike that you asked me to speak on... given that the majority of us prisoners, were just released from indefinite solitary confinement status, many of us were and remain without jobs! And in addition to this, jobs are extremely scarce, which is by design, relative to the state's (police state) overall scheme of genocide population control. Hence, the majority of their jobs are given to their "hand-picked" lackeys. So as far as a work-stoppage went, there weren't too many persons partaking in it from that perspective. However, what myself and a number of stand-up, principled prisoners did was this:

1. We fasted (sun up-sun down) in support of those comrades doing a work-stoppage in other slave kamps (prisons).

2. We held political education classes, where we took the time to educate prisoners on the importance and power of their human labor, relative to the social system of capitalism.

3. We also wrote articles to educate the public and support the prison strike.

-Resistance! Kijana Tashiri Askari [see also Kijana's article "A Revolutionary's Perspective on Nancy Krushan's book 'Out of Control'" on the Maoist Internationalist Movement website and for more of his writings, see kijanatashiriaskari.wordpress.com]

\section{Jeremy Valerio, FCI Otisville, New York}

I received your message and wish to give it response but before I do I wish to inform you that my present situation does not allow me speak freely about strikes as it would be talking out of place besides most of my time has been spent in the SMU. Special Management Unit or the S.H.U. Special Housing Unit. So I wasn't present during the strike, and here in the federal system there's no unity among these captives. They are so brainwashed with reality TV, hood novels and anything else that is not about self development, that I've come to stand alone on a lot of issues that needed to be addressed at my last few pens. 
I'm now in the process of fighting for my freedom and may be getting this time back and sent home before summer is over with and that's when I'm going to let it be told and bring fire to the prisons. - Stay Strong! Jerry Valerio

\section{STRATEGY: INTERFACING WITH PRISON HIERARCHIES}

Some prisoners suggested interfacing more with existent prison hierarchies, specifically gang leaders. Prisons produce certain destabilizing social dynamics that sometimes necessitate gang involvement for survival, protection, camaraderie, and/or collective efficacy. Additionally, a number of gangs in the U.S. have their roots in resisting white supremacy, class oppression, and police terror, and it is not unreasonable to imagine that gangs can serve a political function, as it does in the free world (Baltimore gang truce, North carolina almighty latin king and queen nation, for examples.). On a practical level, interfacing with prison hierarchies in terms of getting information in and communicating messages throughout a facility, gang and/or religious leaders often have the means and the reach to send information quickly and effectively, much like anonymous in Michigan notes. As anarchists, we are skeptical of any hierarchies, especially those based in the coercive or manipulative influence that prison leaders may have if they give an order, since, as Adrien puts it "no one would dare go against it." We see interesting opportunities here and the nuances of such a tactic necessitate further discussion. Kijana states that these prison hierarchies are a part of "petty prison culture" which actually prevents the creation of a united front among prisoners. Last, Kinetik offers a different take on gang and religious leaders, which is that they can provide a framework for the call to action that speaks greater volumes to their crews.

\section{Anonymous, prison in Michigan}

After our first peaceful protest which was awesome, someone reached out to me and wanted me to fill him in on what was happening here. Once we got acquainted he brang it to my attention about a nationwide protest work stoppage on Sept. 9, 2016. I did not want to bring direct attention to myself because they could retaliate and transfer me to a higher security level with trumped up charges. So what I did I gave the news to the heads of the religious groups and the head of the gangs. As well as those renegades and those loners I

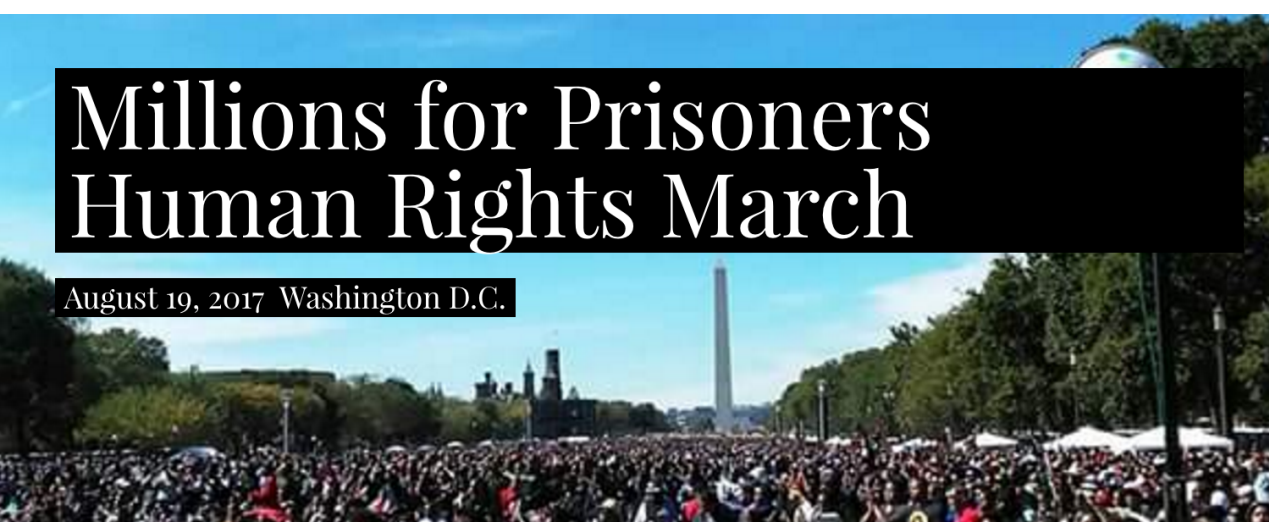

\section{MOVING FORWARD}

Prisoner strikes, rebellions, and protests, as well as outside organizing have continued since the Sep. 9 actions. During this time we've seen many outside supporters shift away from prison struggles into antifascist organizing in response to the Trump election and surge of far right activity. At the same time, the steady increase in dedicated support for prisoner resistance in radical communities continues. Often the same people are spreading their time across both of these concerns. We present The Fire Inside from a desire to maintain and refocus struggles against the criminal legal system as a whole, rather than merely its most nightmarish manifestation. As important as it may be to stem the present tide of right wing extremism, we must also recognize that the longstanding democratic government it threatens was already locking up, enslaving, and torturing people--particularly black, working class and queer people--in greater numbers than ever. Remember, without the cops and the prisons, Trump and his fanboys would be powerless.

On that note, we're excited about the upcoming August 19 Millions for Prisoners March, which was called for by Jailhouse Lawyers Speak and other inside/outside networks. Readers can learn more about August 19 and participate from wherever they are by visiting IamWeUbuntu.com. Unlike the Sept 9 call, Aug 19 focuses on marches and rallies on the outside, rather than inside actions. The biggest challenge of this work is communication, particularly about support levels. Demonstrations of robust outside support, like those being 
4. Another area that could use a little work is finding more dedicated prison approved media correspondents. This will give the public a chance to learn about what's going on throughout the nation while simultaneously giving us the liberty to send our reports that aren't delayed or banned through mailroom censorship. Our first struggle seemed a bit slow which was probably due to mailroom scrutiny and the few media correspondents around choosing to focus on popular prisoners as opposed to those who could provide anecdotes for their articles, since there prisoners were in the midst of the event.

5. After correcting the censorship problem we could focus more on realizing what prisons will participate, then locate particular participants at each one to send in reports and other critical information. John Washington, who was reporting for The National Magazine, released a preamble on the work stoppage; but from my knowledge he never followed through with an article on what prisons were at a standstill. I believe this was due to a lack of flexible journalism coupled with the prisoners being unorganized and unaware of when and who to send reports to. This method will also make it easier on the recipient of the reports; since it will quell the amount of redundant mail has to scan through, relay and reply to.

6. In our first wave the date was set on the 45th anniversary of the Attica Prison Rebellion. This was a great day to do such a thing, but since it was emphasized so much; prison officials were aware of it just as much as we were. This beforehand knowledge resulted in the prison I'm housed in to be put on lock-down on labor day to prevent any possible disturbances. As for the new day, it will be better if those on the inside are given the chance to circulate it, as we all know when it is. It will also be helpful if this date is redacted from literature that will be censored by the prison mailroom. Mailrooms feast on such mishaps and often obtain info that can be used against us. Just because they allow some literature concerning our event to slip in, doesn't mean that they aren't using the info to stay a step ahead and disrupt our plans. - ALL POWER TO THE PEOPLE, Jason knew if the masses would move to one beat the others would fall in line. Once the seed was planted all through summer I watered it by talking to the most influential men of the compound. So 9/9/16 became a big thing, however, no other prisoner who was influenced were taking the word to other prisons. That is why a lot of the other prisons did nothing because they never got word.

\section{Adrien Espinoza, ASPC Kasson, Arizona}

You need to coordinate with the open yards in Arizona (non-pc, nonsex offender), where politics reign. If you can get politics on your side you'll be golden. And by politics I'm referring to the leaders/spokesmen of each respective [racial group] or [gangs]. These racial factions are oppressive, true, but the enemy of my enemy is my friend. If a leader of one of these groups gives an order (such as to strike) no one would dare go against it. Most of these leaders are all about money and selling dope so I'm not entirely sure how you would convince them to cooperate with a strike. Get [them] to coordinate a strike and you could likely get it to go statewide... I spent 10 years in these units and around these commanders, so I know. My own organization is too few; plus, we do not have an open line of communication so my own influence is almost nil. - Sincerely, Adrien Espinoza

\section{Kijana Tashiri Askari, CSP SAC, California}

The primary lesson learnt from all of this, is freedom is a constant struggle! The united front that we formed while entombed in the state's domestic torture units, has not transcended to the general population mainlines, from the standpoint of collectively resisting the multitude of injustices on these mainlines. So the issue remains, how can we sustain our resistance long-term, when consistently confronted with the politics of the petty prison culture (PPC), i.e., "drugs, gangs, racism, tribalism, political immaturity, etc."? Resistance! Kijana Tashiri Askari

\section{Kinetik Justice, Limestone Correctional Facility, Alabama}

MATT: There's some perception of people outside, or even inside the prisons probably, that heads of religious communities or heads of street gangs are not interested in politics, or they're just sort of interested in religious issues, or their own leadership of a certain 
group of people, or sectarian issues, but that doesn't seem to be the case here and I wonder if you could just talk about that experience... KINETIK: Well that was it exactly. In organizing, knowing the people, the needs-you gotta get amongst the people and once you talk to the people you know what the issues are with the people. It's natural for people to be more attentive to things that affect their daily lives, and when you can talk about things that affect their lives then it's usually all ears. Especially if you can come up with a solution to the problems that they have, then people are a lot more inclined to be on board and that's what we were able to do. It's a given that since I've been in prison I know the issues that are affecting people. I know how to communicate those issues, and I know who to talk to inside the institutions so like I just talked to the leadership, and the leadership is gonna take it, and they package it in a way their congregation can accept it, and you know if you can convert the leadership, you convert the flock.

Excerpt from an interview on The Thread: A Podcast against Mass Incarceration, episode \# 1

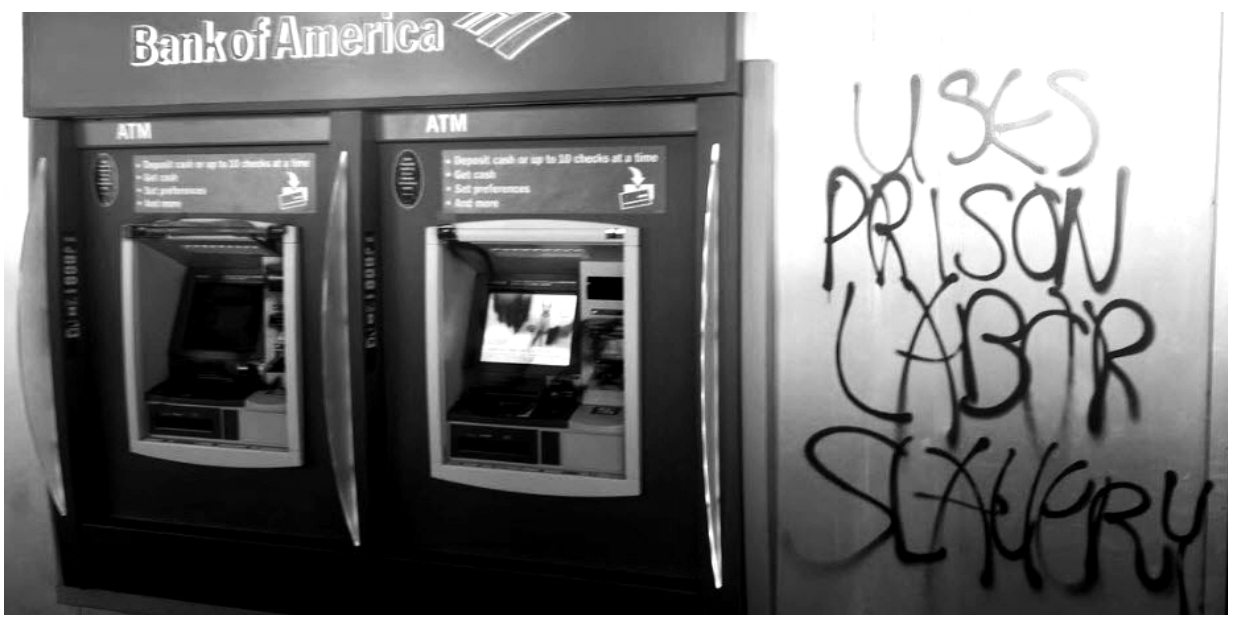

SUPPORT: WHAT WORKED

Prisoner support and its importance cannot be overstated. Prisons serve to silence and disappear peoples. Prisons serve to kill the human spirit and to weaken political defiance. In our first entry, Hakim beautifully writes about how important interpersonal relationships and emotional support can be to keeping the spirit alive, given the publishing anything or giving interviews you re-verify any critical information relayed from anywhere by contacting the prisoners or their supporters. Never rely on what prison spokesmen or the warden's secretary say. Their aim is to restore order, not be truthful. No need to rush!

2. Most of the information that's relevant to prison life comes from publications like the San Francisco Bay View, Prison Action News, Incarcerated Worker Newsletter and Socialists Viewpoint Magazine. On a scale of cost vs. benefits, the benefit of reading something that's common knowledge i.e. the fact that a second effort is being made, don't outweigh the cost of a series of publications being rejected for the exact same article. To counter this it would be wise for media outlets to only publish content that gives us new insight while reducing content that normally gets banned that we are already aware of... As much as I don't agree with censorship it's better not to print something at all than waste resources on something we all know will be denied.

3. During the first month of publications released that gave an update or spoke on the campaign, I noticed most of the reports I read lacked accounts from prisoners that were engaged in an actual work stoppage at their prison. To my disappointment, the focus seemed to be on publishing rehashed sentiments from prisoners that weren't actually refusing to work, but whose influence with grassroots media outlets sensationalized their input. I suggest that supporters and media correspondents that will be keeping tabs on our struggle learn who the charismatic resisters are at each participating prison and rely on them for insight, writings, data collecting, etc. in order to get a comprehensive account on the general event as opposed to academic and subjective views and analysis. Our use of media outlets should be to give each resisting prison a voice, not pick one or two prisoners then use them as the speakers for the entire event; when in fact our reasons for resisting, how long we will resist, and the reprisals vary from state to state. For instance, if members of the Free Alabama Movement decide to call it quits this technique will prevent the start of rumors that the work stoppage is over, while clarifying what prison has folded or got their demands met. 
actual stop date. But again, they missed the mark. What needs to be realized is that information in prison spreads slower than information on the outside. Most of us rely on snail mail which takes several days to send and receive and that's if the mailroom doesn't ban it so once we or the public receive a message, things have changed either correspondingly or contrarily. This is why the botched radio interview caused so much harm.

I was approached by the several prisoners who'd listened to the interview, giving me the heads-up that the campaign had ended. In my opinion this interview itself was the coup de grace to the movement here in Texas. NPR is a very popular radio station in Texas and being the only daily national news station retrievable here at the Clements unit in Amarillo, Texas; we are forced to take the info at face value. Since other odds and ends caused delays in our communicating to the outside and general struggle, I will list what I saw as errors and propose a comprehensive list which will correct these mistakes and strengthen our effort in moving forward.

\section{List of Errors}

1.Free lance writers and independent media correspondents circulating reports using untrue and unverified information

2.Multiple grassroots media outlets printing the same redundant information on work strikes, which continuously get denied by the prison mailroom

3.Our failure to recognize and round up the most advanced writers, poets, artists, speakers, organizers, etc. and making them the face of the campaign as to build up its prestige in the public

4.Our failure to locate more versatile prison approved media correspondents that are flexible enough to communicate with more prisoners than impractical popular faces

5. Our failure in creating a body of organizers within the belly of the beast, who are used for the purpose of sending our reports at their particular prison on progress, space conditions, reprisals, and any problems that occur during our national struggle

\section{Proposed List to Correct These Errors}

1. To any published writers, journalists, or media correspondents that choose to report on our progress I recommend that before alienation that prisons. He also speaks to the many instances of prisoners being fractured from their families and/or communities and how valuable human connection can be in that instance and throughout a struggle that is, for most, a lifelong process. Mutope also emphasizes the role of supporters, both in providing practical support to a collective cause, such as publicizing struggles on social media, humanizing prisoners' issues, engaging in protests and petitions, and providing bus rides for prisoners' family members as well as simply being present when no one else was. Cesar recognizes supporters' ability to break the silence that the prison state wishes to impose by uniting around gaining attention for the bold acts of resistance on the inside. Jason commends this greater awareness raised about prison profiteering and also references an article he published on truthout.org, which merges the importance of prisoner-centered knowledge with fueling greater interest and attention among the free readerships. For Jason, there is huge importance to how the strikes throughout 2016 [and previous regional strikes in 2010, 2012, and 2013] resparked a prisoner resistance movement from which to build on. Khalfani agrees with the personal value of support in fueling determination and political will. He also cautions supporters to develop strong rapport and that they must avoid exploitation and misrepresentation. Khalfani asserts that supporters should try to establish meaningful relationships and strongly recommends inperson visitation.

\section{Hakim Akbar-Jones, CSP Corcoran, California}

Support provided in the above said does provide any prisoner comfort of a mental, emotional, and wellness level that does up lift the morale. Most prisoners such as myself have little to no support from our side. People who regularly depend on those around and camaraderie amongst peers. The institutional practice of punishment does destroy humanity in spirit and morale when no support exists or becomes available. Prisoners have little to nothing of materials compared to that of a free person, but yet free people also have insufficient finances to maintain certain levels to live by, so there is some apprehension and stinginess when providing financial support. Most prisoners have nothing and work for pennies if they have prison jobs. In solitary, we did not receive much mail - nor have access to resources. Most magazines had ads for penpal services that cost. I had no financial support or any help for years from family or friends. I had no one other than my neighbors. I don't mean to make this about 
me. It's just my continued healing process in solitary confinement has caused me and my reflections. But i would experience not only was I in this condition, pretty much we all were. At least 4 out of 6 people! I wish I had many people to write to, share affection, wisdom, knowledge, and life with. I wish I could feel a caring and loving touch from people who care at visits, even if it were behind glass windows. Just having someone in front of me to look at, connect with, and missed dearly. It's like, without it, I was looking into straight darkness hoping to find people I could connect with but no one was there. Those were the hardest and darkest times in solitary confinement. I held on to what love developed before my long journey in incarceration. One of my biggest love inspirations were the happy feelings music gave me. It was medicine for my soul. Very soothing when I would think of reggae, neosoul, jazz, classic rock, R\&B/Soul, and gangsta rap. Gangsta rap and reggae described my journey and was a representative of it. It was the rhythmic beat and tones that would help me vibe throughout the day.

I/We wish there were more people there for us during our strike unity and solidarity movements. How we became above ground and recognized through writing to newspaper outlets relentlessly begging, pleading for ears to hear us. It took 11 years for people to catch on to what we've described as human torture of the soul/spirit by way of solitary confinement and incarceration. Brutality and beastality by prisoncrats and capitalist pigs. - Hakim Akbar-Jones

\section{Mutope Duguma, cofounder of George Jackson University, Calipatria SP, California}

We engaged the world[!] We had so many people on the outside - it was awesome because they heard our cries. Our outside solidarity was [powerful]! People came out in droves to keep our movement in the media, when the media refused to cover it.

There were several functions that our outside supporters served: (a) Our supporters waged a social media campaign against the state. (b) [They helped us] solicit the legislative body while waging our peaceful protest against the state. (c) Our supporters made human rights brochures and posters, which actually humanized us to the world. (d) They established bus rides for family [members] to visit their families. (e) They told our many personal horror stories to the
Solitary Confinement until after the storm of the National days of Protests was over. I was released back in the general population on September 13, 2016. While many of my events Hunger Strikes, letter Writing Campaigns, etc. There are always lessons learned. With last year's Protest and resistance. We have to always alert organizations who are in Solidarity with us 30 days ahead of time. We have to plan for prisoncrats coming to isolate known leaders in hope of stopping the resistance. We should have a lawyer in each state to aid comrades who come under attack by their Plantation Runners. Prisoncrats Administrators don't like attention or lights shined on their exploitive actions of Prisoners or acts of Widespread Cruel and unusual punishment. I have managed to get a lot of bogus charges overturned or reduced or even modified because of outside Supporters calling on them to reconsider, plus having them open new investigations.

Having devoted/loyal Supporters on call is extremely important. See also PrisonRadio.com for Khalfani's taped interviews. - Power to the People! Brother Khalfani

\section{Jason Renard Walker, Clements Unit, Texas}

Propagation tools, like news and media outlets are key to our success. They keep interested parties informed on our progress and regress. Since it is up to prisoners resisting within the belly of the beast to convey inside info to the outside, any public supporters that choose to pass this message to prisoners in other parts of the country have to stick to the specifics. Watering down and politicizing our words can cause more harm than good.

During an interview on National Public Radio two [people speaking on behalf of the prisoner strikes] stated that the national prison work stoppage was over. Neither mentioned where this info had come from, which gave the interviewer the opportunity to use bourgeois rhetoric to change the core question to "was the work stoppage a flop?"

Their failure to clarify that we'd just begun gave a big blow to the project and insinuated that it really was over. The death punch came when [one of the interviewees] claimed that a prisoner somewhere stated to someone that he wanted to know when the next prison work stoppage would occur and how he could get involved. [ The interviewee] could've repaired some of the collateral damage by stating that he or anyone could get involved now since there was no 


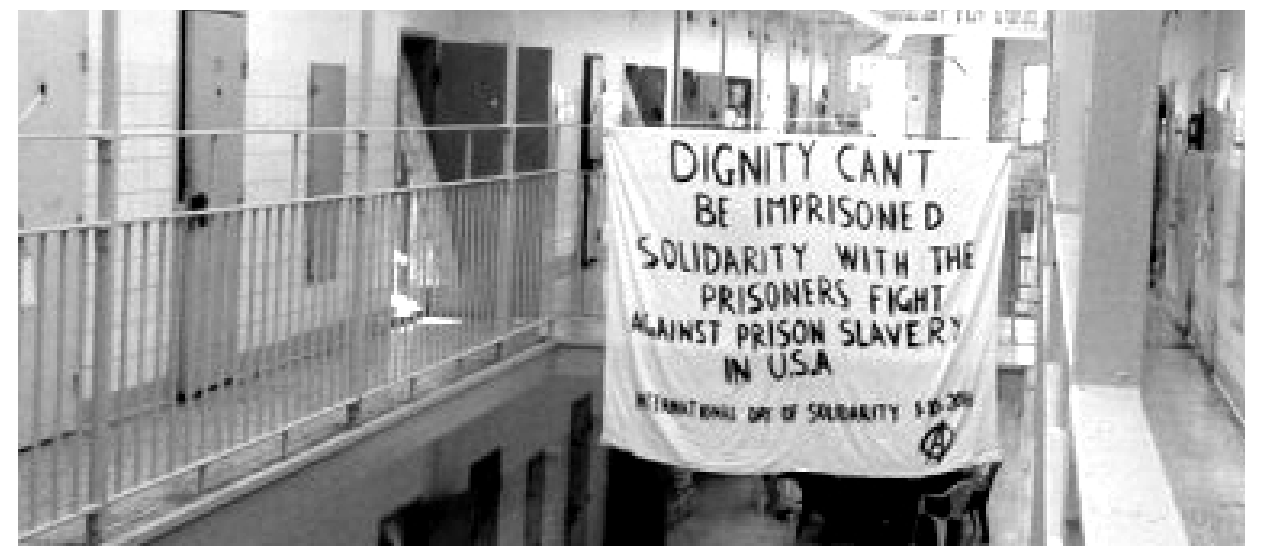

\section{LESSONS LEARNED}

These contributions describe specific experiences and identify mistakes that should be accounted for and avoided in the future. Khalfani talks about being pre-emptively transferred to segregation before Sep 9, because he had been identified as a prisoner leader and the need to prepare for such events. Jason Renard Walker goes in depth about the limitations of media strategy. Reading his letter completed a picture that we as outside supporters only saw from one side. Organizers in Texas--including the person who Walker describes giving bad information to an NPR reporter--were scrambling to find and confirm information about activities inside. We knew there were lockdowns across the state, but the prison admins lied and released contradictory information, and folks also received conflicting reports from different contacts within the same prison, or even the same unit. Hearing that prisoners were similarly searching for information is frustrating. Jason's wish list of improvements to media and communications strategy are great goals we should strive for, and recognize that we've got a long way to go to get there.

\section{Khalfani Malik Khaldun, Wabash Valley CF, Indiana}

Comrade, I was snatched out of General Population on August 19, 2016, shortly after a visit will a local coordinator with (Indiana-IWOC). This comrade (3) days after the visit sent out 700 alerts on the national Day of Protest. Calling on a massive Work Stoppage. The IDOC Commissioner and Assistant Superintendent of this plantation had me placed under investigation. They told me I would be in world. (f) They [helped us] file law suits and petitioned the United Nations. - All Power to the People, Mutope Duguma, cofounder of George Jackson University

Cesar DeLeon, Dying to Live campaign, Racine CF, Wisconsin

The Dying to Live campaign was organized to bring awareness to the issue surrounding the long term solitary confinement in the state of Wisconsin. And it lasted around $71 / 2$ months. Thanks to the support of religious and prison focus groups the campaign gained publicity and public awareness for the first month or two. Activists and supporters took to the streets of Milwaukee, Madison and other counties to march in support which gained us a major burst in publicity. The campaign was a success. We demonstrated our ability to organize and our will to fight the oppressive prison conditions of confinement. This campaign also brought a lot of activist groups together under a single cause which gives us hope that we all want the same things and working together is a way we can obtain it. - Cesar

\section{Jason Renard Walker, Clements Unit, Texas}

Prison officials are aware of the economic damage that can result from prisoners peacefully protesting inhumane living conditions, poor health care, and unpaid forced labor. So even the slightest flash of organized resistance will draw an oppressive reaction. Their aim is to disrupt any progress, separate the most advanced elements, and deter others from rebuilding to carry-on. Many of us faced some of these problems during the first wave which included sudden unverifiable rule changes, illegal moves to solitary confinement and the disregard of rules entirely. But there were also some positive things that happened - which I will now touch on.

Through this very short lived act of civil disobedience came journalists, writers, activists and concerned members of the public who were unaware that prisoners were being subjected to such treatment. Small rallies were held, articles circulated and worldwide awareness was brought to the U.S penal system as being one that operates to profit off forced and unpaid labor. This being done with little regards to our health and safety. The same week of the national work stoppage campaign I wrote an article for the progressive website "truthout.org" titled: "unpaid labor in Texas prisons is modern day slavery." This also raised some awareness as several 
readers spent hours debating back and forth in the comments section on prison slave labor and other issues.

We must also remember that it was the resistance throughout the U.S that marked our plight as the first national prison work stoppage to ever take place in America. Without this practical attempt no one would've acted and aided us as much as they did. The reason I believe the first attempt was a success is because we were able to build support in places that previously had little interest in what goes on in prison. We were also able to get confirmation that prisoners across the U.S had a common interest in struggling to create better prison conditions. This goes to say that we've created a firm platform that will help us move forward we just need to be more firm in our standstills. - ALL POWER TO THE PEOPLE, Jason

\section{Khalfani Malik Khaldun, Wabash Valley CF, Indiana}

Comrade, preparation is key when engaging in a massive show of Resistance. The support from outside should initially come by way of letters to active participants expressing solidarity \& love or pictures, money, etc. for years while i have been on the frontlines of activism inside the indiana Prison Plantations. The support letters and financial assistance aided in my survival, my motivation, and the energy fueled my determination. Prison activists need to know and physically See that you're not simply trying to exploit their struggle related events. Knowing you do actually have their backs is a powerful encouragement that the Sacrifices they're making isn't in vain. [Also] outside emergency response coordinators should network immediately with (5) active prisoners at every Prison in the state they reside in to ensure we are on the same page. Visits also helps to build more realistic bonds with the Political prisoners and Prisoners of War who Supporters claim to be representing. People who actively followed the updates of the resistance and who showed their opposition to Prison exploitative Slave labor and sent me letters from multiple grassroots organization, stating that i was loved and never forgotten. These letters were like medicine to my Soul and heart. Social media was the window we needed to Coordinate such a large call of resistance. Social media became our window to the world. See also PrisonRadio.com for Khalfani's taped interviews. - Power to the People! Bro. Khalfani [see more of Khalfani's writings at bloomingtonabc.noblogs.org/post/tag/khalfani-khaldun/]

\section{Edgar A Sazo, Gib Lewis Unit, Texas}

The situation here on Gib Lewis was, at the time of the strike, confusing to say the least. All of the workers knew when to start as I was informed by the IWW but after we started we didn't know how many days we were expected to continue, we didn't know if the desired effect was taking hold, we didn't know if other units were doing anything, then when they placed us on lockdown we were not sure if it was a routine lockdown or if it was in answer to prison worker efforts. When we came off lockdown we were in the blind so everyone started working as usual. Also many workers who had committed to the action did not follow through, some for fear of repression, others because they did not want to face disciplinary action for refusing to work and still others because they simply did not believe the strike was real.

I am not by any means a good organizer but I know because I was unable to provide constant information to those who were striking everyone just became disillusioned with it as if the IWW or anyone else just didn't care or even knew what was happening. I think now we will operate under the assumption that we are doing this "inhouse" so when there is no communication no-one is disappointed. I do think there should have been way more information flowing to the prisoner workers but because I have personally had letters stopped and refused to me because of the letters "advocating prison disruption" then I would recommend that there be at least one freeworld organizer on at least one prisoner organizing visitation list so he or she can maintain contact that's not as vigorously policed as mail. Maybe they could visit once a month or more frequently during a strike to keep info flowing in and out of the walls. - In Solidarity, Edgar A Sazo

\section{Britney Gulley, Skyview Unit, Texas}

Whenever initiating a strike always keep in my mind you may not receive support from outside. The prison system has its flaws of corruption and the main pipeline is shutting prisoners off to outside the walls of prison. So support is not always a guarantee. You must strike as if the battle is meant to be fought alone... - Britney Gulley 
on to something else. I've witnessed and experienced this many, many times. You asked me to give you advice on [a couple of things]:

Organizing and preparing for a strike - It must be a collective consensus of all the participants on what the strike is about. Is the issue regarding the strike essential enough for the participants to risk their health and possibly their life? And is the outside support strong enough to support the prisoners? How to provide support - Support is provided via consistent letters, phone calls, and visits. These forms of communication are essential in building trust and loyalty with people, especially prisoners. Oppressions are not extinguished by mere words. Actions must be manifested. So if people know that people got their best interest at heart unconditionally they'll be more inclined to support a cause. But please remember that in order for this to effectively work, you and your organizational members must communicate with us and other prisoner-participants via phone calls, visits, and letters. - Habi, Comrade Khaysi [see more of Khaysi's writings on rashidmod.com]

\section{SUPPORT: PRISONER INDEPENDENCE}

Fences and walls are not the only barriers between prisoners and their outside comrades. Prison is in many ways a shadow world where limits on state power do not apply and people are forced by conditions to adopt different social norms and cultural expectations. Often prisoners have nothing but time to think and plan, but no access to tools for executing plans, while their outside contacts have access, but are inundated with distractions and the time consuming routines of daily life. Most importantly, communication can be heavily monitored and frequently interrupted by either petty mailroom staffers, or official censorship. As a result, outside support can seem very unreliable. The following contributions speak to different ways prisoners may adapt to this reality. Edgar sees the pitfalls of striking when communication is sporadic or becomes censored; he advises setting up designated contacts with visitation access. Britney suggests that perhaps prisoners should expect outside support to fall short or be blocked and be prepared to act independently of support. Meanwhile, we hope the contributions from outside organizations share some best practices to improve and develop more reliable support efforts.

\section{SUPPORT: WHAT WAS NEEDED}

The many challenges of organizing across prison walls and fences make our efforts incredibly difficult. The shortcomings described in this and later sections make it clear that we do not currently have the capacity needed to unlock the full revolutionary potential of prisoner resistance. Thus, the task before us is two fold; while maintaining our commitments to correspondence with organizers, we must also inspire and recruit greater involvement inside and out. We must also be realistic. Inspired supporters who take on the cause with great energy, and then drop off when times get hard or a crisis develops put their inside contacts through psychological roller coasters that can have devastating consequences. In this section, we hope to identify and build toward better approaches to these varied tasks. Mutope speaks to expanding the scope of support to reach beyond those dedicated to just prisoners' rights but human rights in general. He suggests reaching out to family members and getting them active, as well as building more robust legal support, and more media and community outreach. Cesar underlines the need for legal support, not only to defend current strikers, but to recruit more and more effective media. $P$ recommends more prisoners get better informed and prepared for disciplinary actions, psychological warfare, and other prison retaliation methods. Texas Swamp Monkey likes to see supporters calling the prisons ASAP, pushing counternarratives, and better buffering against state repression. For Comrade Khaysi support must move beyond words. It needs action. He poses some hard questions for supporters to grapple with.

\section{Mutope Duguma, cofounder of George Jackson University, Calipatria SP, California}

The best steps that generates outside support are: (a) Calling on all local/state activist organizations that are serious about civil/human rights. They are our first line of defense. (b) Establish a statement that will speak to why we are taking such an action, and our demands. (c) Explain to the families of prisoners, the mothers, grandmothers, aunties, etc, as to what's going on with their family behind prison walls, in order to get them active in the movement. (d) Seek a law firm to [properly] represent the legal aspect of the struggle. (e) Speak wherever you can to get the message out to ordinary people - do flyering [events] and protests in order to get people involved; contact all radio stations in local/state to get them informed as to what's 
happening around our movement. People have to be sold on how their actions will make a difference. - All Power to the People, Mutope Duguma, cofounder of George Jackson University

\section{Cesar DeLeon, Dying to Live campaign, Racine CF, Wisconsin}

Unfortunately, we lacked a legal support team that could help the hunger strikers defend their constitutional rights to hunger strike and to defend us against the harassment and physical abuse from the prison officials who desperately tried to stop the movement from gaining support. Had we had legal support I believe more inmates would also have joined the strike which could have kept the media's interest. If I had to do it all over again I would recommend that we first get some civil rights legal groups to back us up all the way. From filing a lawsuit of the subject matter surround the protest, to filing open records requests to get videos and other documentation that can be used to gain publicity. The public are visual creatures. To keep that publicity we need images that show the horrors of being force fed, etc. Nevertheless overall the campaign was a success and a learning experience. We all played our roles to the best of our abilities and did everything we could. - Cesar

\section{$P$, Waupun CF, Wisconsin}

I wish there had been more prisoners involved that aren't swayed by their fear of Waupun correctional institution's segregation building and won't back out at the 11th hour. Key lessons learned were, trust that a lot of those involved will psychologically break due to Waupun Correctional Institute's segregation, thus bringing rise to betrayal and snitching/false accusations made against [strike participants]. Ideas for better strategies would be to maintain focus on the issue at hand and be sure those prisoners involved are fully versed in their rights as a protester and the WI DOC 303 disciplinary codes, being likely charged, the new D.A.I. disposition penalties they face. - "You can tell a lot about a person by the way they treat those they don't have to treat with kindness." In solidarity, $P$

\section{The Texas Swamp Monkey, anon prison in Texas}

It is imperative that as soon as these units are placed on lockdown our free-world comrades should wait about 3 days and then begin a well coordinated campaign of harassment. Calling the unit, sending emails to high-ranking officials and legislators as well as engaging the media. The last thing you want to do especially in Texas is allow the pigs to craft every narrative made available to the public because experience has shown us TDCJ and Alabama DOC will paint the prisoners in the worst light possible in order to justify civil and human rights abuses.

The work stoppage is an excellent strategy to draw free-world attention to our struggle but it is worthless without free-world comrades to speak to the media on our behalf. In prison you have inmates who talk a lot of shit like they are down with the movement but when things kick off they freeze up and fold. They can't handle the "heat." Free-world comrades also suffer from "stage fright." Not all, but some. When the pigs start pressuring our free-world supporters they get scary!! We need to distance ourselves from these comrades - FAST!! We certainly aren't condoning or promoting any violence. Truthfully, we don't have to! Once we start letting these crops rot in the field and shut down the factories it won't be long before negotiations will begin. This will be a mass movement. Soon the world will know the United States of Amerika has a serious problem. Turning a broad swath of the population into 'legalized' slaves was the dumbest thing the founders of the nation ever did. In order to rebuild this thing we must Destroy Imperialism. - END. The Texas Swamp Monkey

\section{Comrade Khaysi, High Security Center, Rhode Island}

I did a 27-page petition while I was in Virginia/Red Onion. This petition is part of the reason the Virginia prisoncrats transferred me out of state to Rhode Island on June 16th, 2016 because I was able to mobilize a lot of prisoners to challenge the sadistic conditions inscribed in my petition. I concur with the concept of uniting different peoples and organizations around addressing injustices,

discriminations, sexism, racism, homophobia, etc. in and outside these plantations. Here's my only problem with doing this. Through my experiences in this type of movement. It stops at only writing essays, newsletters, pamphlets, etc. The people on the outside mistakenly think that writing essays, newsletters, and pamphlets about injustices, discriminations, sexism, racism, plantation abuse against prisoners, etc. is enough to extinguish this malfeasance. Once they realize that more is needed they eventually burn out and move 